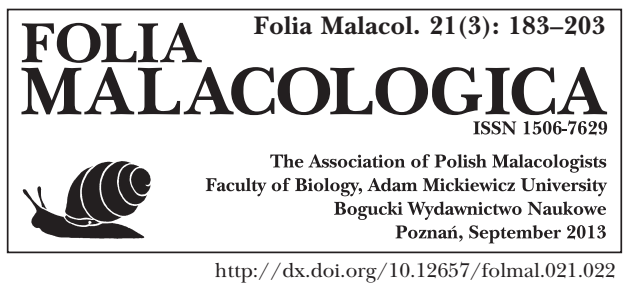

\title{
THE 29TH POLISH MALACOLOGICAL SEMINAR
}

\section{SEMINAR REPORT}

Oh, hard is the fortune... I have barely finished the 28th Seminar Report, or so it seems, and here we go again! It is very difficult to write a DIFFERENT seminar report each year, that is unless something unusual happens, but nothing does. Open the previous seminar file, copy and paste? Never! I'll try to approach this one from a slightly different angle, and if you recognise some bits of the last year's report here, it will only mean that the things have not changed, OK?

Why so few people? The list of participants (the last pages of the Abstract Book) included 36 people, but two of them were representatives of the sponsoring companies, which leaves 34 proper malacologists, and at least five of them were FTAs [= failed to appear]. By the way, the Abstract Book included 3 abstracts by a total of 7 authors from Zhytomyr, Ukraine (somehow every year the composition of the Zhytomyr contingent changes, but they never appear in person, so maybe it is good that they were not listed as participants). There was one extra participant, TEREZA KoŘínKOVÁ (the Czech Republic) who seems to be our faithful fan and this year was the only neighbour who decided to join us. Thus the number of actual participants was around 30 (Fig. 1), plus one non-malacological husband, one

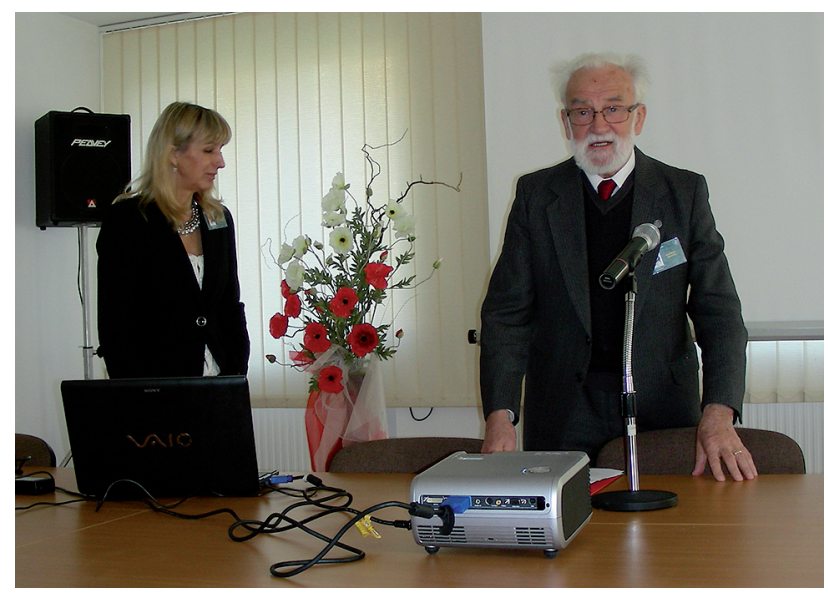

Fig. 1. Professor ANDRZEJ WIKTOR chairing. One of the organisers, BRYGIDA WAWRZYNIAK-WYDROWSKA, modestly on the left. Photo: Author non-malacological wife and one baby (as to the baby we are not sure, she may yet grow to be a malacologist, the earlier you start, the better) (Fig. 2).

Well, I have digressed. So why so few? Some people complained about the distance which, I think is... well, not really sensible, to put it mild. After all, ours is a big, squarish country, so wherever we hold our Seminars, some people will have to travel far. A more serious complaint, and by far more common, was that about the finances. Mind you, not that it was so much more expensive than the previous one, because it was not. It is just that the financial situation of most, or even all, scientific institutions is deteriorating and when it comes to a decision "do I prefer to go to the Seminar, or do I prefer to have a field trip, or to buy molecular chemicals, while there is only so much

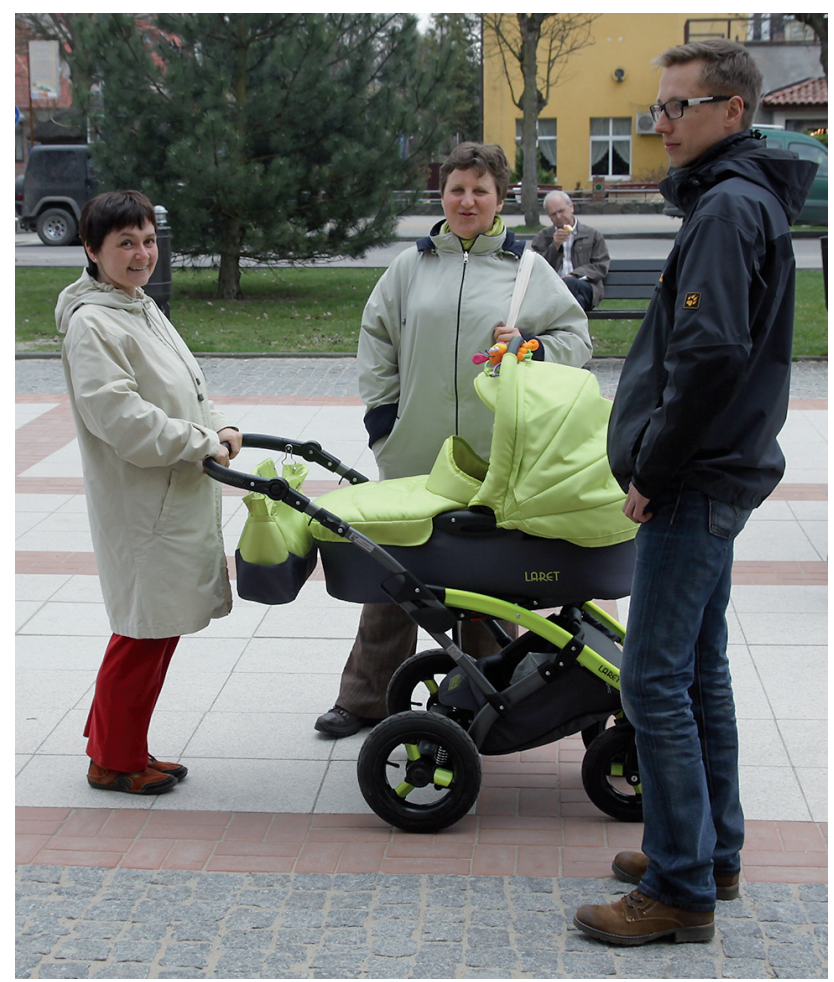

Fig. 2. The youngest participant. Photo: ELIZA RYBSKA 


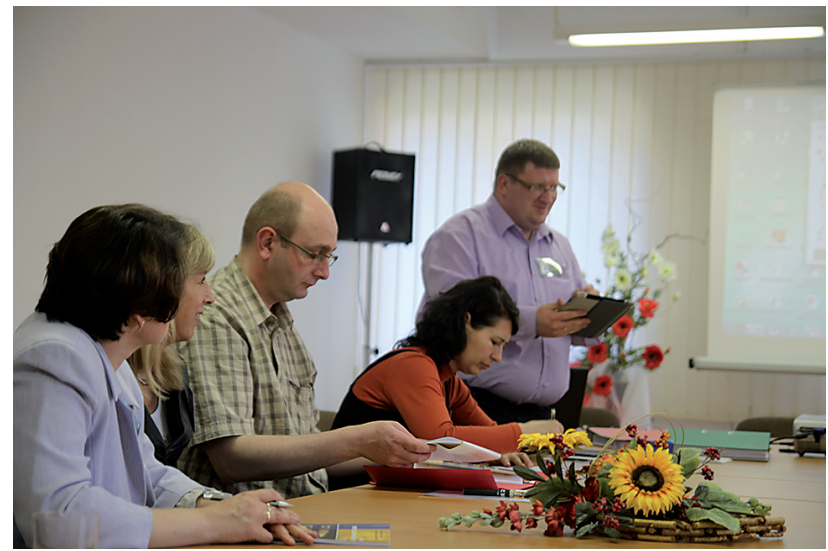

Fig. 3. During the meeting of the Association of Polish Malacologists. The President speaking. Photo: ELIZA RYBSKA

money to spend?" many people prefer to spend their money on something that will directly advance their scientific progress. Also, considering the objectively high cost, I bet many students just can't afford to come which is a shame - it is the students that profit most. Another problem is that nowadays, whatever we do scientifically, we must consider how many points we'll score. Conferences are not exactly highly valued by the system. Anyway, coming to the Seminar also advances our scientific progress. Sharing ideas, starting co-operations, discussing new projects late at night these are the things I wouldn't easily resign. On the other hand, all the conference centres or hotels nowadays, when they hear about a conference, sort of automatically interpret it as a business conference and charge us as much as they would, say, a conference of bankers. This is one of the reasons why the General Assembly (Fig. 3) decided to postpone the next Seminar until autumn - to be able to apply for special funds which, OF COURSE, will be (if ever) transferred to our account with considerable delay. I'm writing these words to make you more aware of what everybody knows: that the Council of the Association is really trying to do its best, but maybe we should just

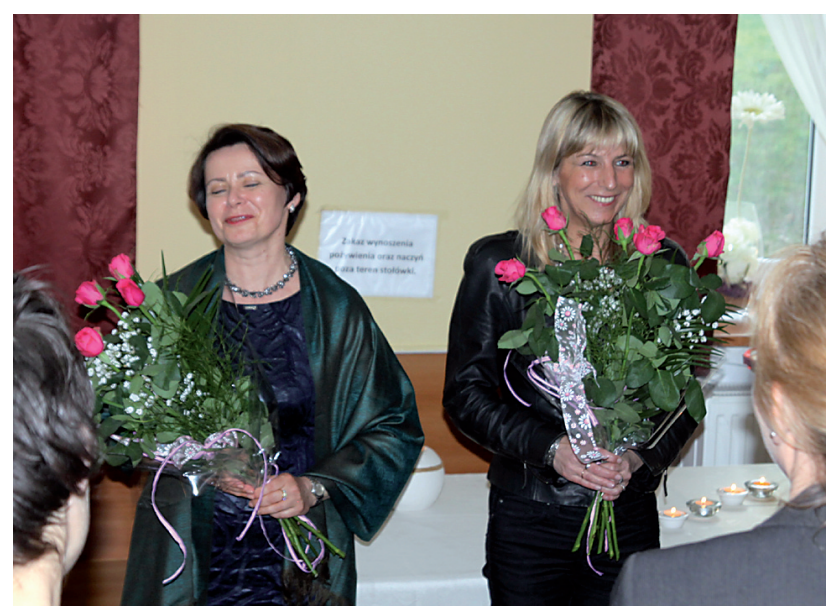

Fig. 4. The organisers: BRYGIDA WAWRZYNIAK-WYDROWSKA (right) and MARIANNA SOROKA (left). Photo: ELIZA RYBSKA grind our teeth and meet every year no matter what. Even without a banquet, or handouts.

The 29th (2013) Polish Malacological Seminar the seminar is the annual meeting of Polish malacologists - was held in Świnoujście (once before, long ago, we had a Seminar there), on the island of Uznam and reasonably close to Szczecin - the home town of the Main Organisers - from April 16th till 19th. Last year I wrote "It was the 28th Seminar, so we shall be thirty soon". Now we'll be thirty very soon indeed. Świnoujście is a typical Baltic coast holiday resort, with lots of nice places where to have scientific discussions but also, during off-season, lots of road works and things going on. The weather was good, in fact climatically it was the first glimpse of spring this year, and we used it accordingly. We all of us stayed in one hotel, which was difficult to find upon arrival but then proved to be rather nice. My only objection was that in some respects it was very communistic. For example, only tea was served at breakfast, and when I asked (politely) if I could have some coffee, I was told "You'll get your coffee during the coffee break". Also, the hotel staff seemed to suspect us of intending to depart without paying.

Three people have habilitated recently: ANNA NOWAKOWSKA and MARIANNA SOROKA (both present at the Seminar) and MAŁgORZATA OżGO (unfortunately absent). Congratulations, girls! Keep snailing!

The organising institutions were Szczecin University and the Association of Polish Malacologists; the scientific committee included MARIANNA SOROKA

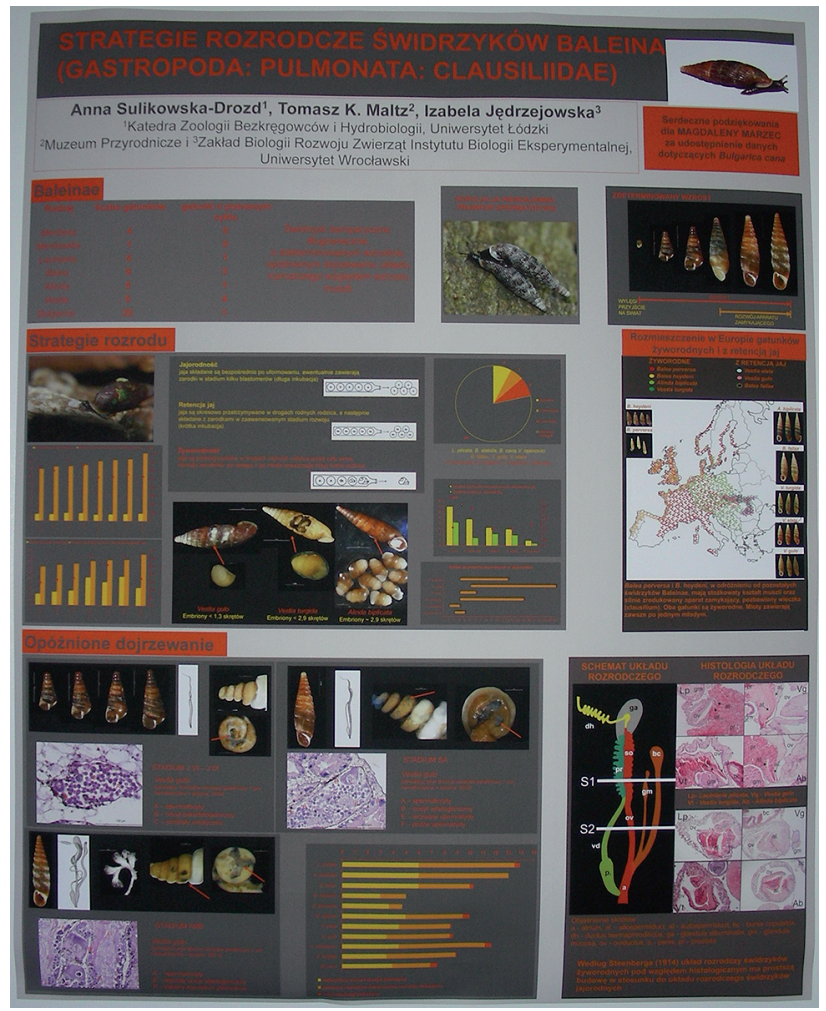

Fig. 5. One of the posters. Photo: Author 


\begin{tabular}{|c|c|c|c|c|c|c|c|c|c|c|}
\hline \multirow{2}{*}{ No. } & \multirow{2}{*}{ Discipline } & 2007 & 2008 & 2009 & 2010 & 2011 & 2012 & 2013 & Total & Mean \\
\hline & & \multicolumn{9}{|c|}{ Number of papers/posters } \\
\hline 1 & Ecology \& conservation & 22 & 29 & 25 & 18 & 22 & 10 & 13 & 139 & 19.9 \\
\hline 2 & Applied malacology \& parasitology & 5 & 11 & 8 & 10 & 11 & 4 & 4 & 53 & 7.6 \\
\hline 3 & Life histories & 7 & 7 & 8 & 10 & 8 & 7 & 5 & 52 & 7.4 \\
\hline 4 & Biogeography \& faunistics & 2 & 4 & 5 & 9 & 11 & 9 & 8 & 48 & 6.9 \\
\hline 5 & $\begin{array}{l}\text { Miscellaneous: general, behaviour, archae- } \\
\text { ology, collections, history, education, meth- } \\
\text { odology }\end{array}$ & 6 & 6 & 9 & 5 & 9 & 3 & 6 & 46 & 6.6 \\
\hline 6 & Fossil molluscs & 6 & 4 & 4 & 3 & 6 & 4 & 5 & 32 & 4.6 \\
\hline 7 & $\begin{array}{l}\text { Systematics/phylogeny (including molecu- } \\
\text { lar) }\end{array}$ & 5 & 5 & 6 & 3 & 2 & 2 & 6 & 29 & 4.1 \\
\hline 8 & $\begin{array}{l}\text { Structure (histology, cytology, shell) \& vari- } \\
\text { ation }\end{array}$ & 2 & 3 & 6 & 2 & 3 & 3 & 5 & 25 & 3.6 \\
\hline 9 & Physiology & 1 & 0 & 1 & 3 & 7 & 4 & 2 & 18 & 2.6 \\
\hline
\end{tabular}

and BRYGIDA WAWRZYNIAK-WYDROWSKA, both from Szczecin (Fig. 4). Good girls! And great thanks! This year the Seminar was sponsored by CARL ZEISS, COMEF Aparatura Naukowo-Badawcza, OLYMPUS, and PRO FOTO Cyryl Przybyszewski, as well as Dean of the Faculty of Biology, Szczecin University. One of the sponsors failed to appear, but never failed to give us money, so why fuss.

Every participant was given a bag, a pen, a notebook, the Abstract Book (which included the programme), and a T-shirt of Szczecin University. The Abstract Book was edited by TOMASZ KAŁUSKI and MAGDALENA GAWLAK and had clausiliids on the cover. Thank you, Editors!

The opening ceremony (Wednesday, 17th) was very short, with only the President and one of the Organisers speaking, and then the real business started. The oral presentations were few and, in all, they took slightly over one day; the posters (Fig. 5) were there, in the lecture room, almost all the time, so everybody could have a good look at them. The chair-persons were (listed in chronological order): ANDRZEJ WikTOR, ANDRZEJ LESICKI, Witold S. ALEXANDrowicz and ANNA NowAKOWSKA. On Wednesday we spent only half a day listening and presenting, and after lunch we went to a short excursion to an old fort which is now a kind of museum-cum-pub (a good idea!), and then we had a bonfire and grill at the fort. The sessions - more oral presentations and the poster session - continued on Thursday and were followed by the General Assembly which this year didn't have to elect anybody, and then by the banquet. On Friday morning we had to say goodbye.

Both the posters and the presentations were very good. The poster technology is getting more and more impressive. Also, some people got new and useful ideas which they presented. WITEK ALEXANDROWICZ and MAŁGOSIA GOŁAS-SIARZEWSKA had a presentation with a rather historic title "150 years of Quaternary malacology in Poland", but it was actually about a new database which, once finished, will certainly be very helpful to those who deal with any Quaternary molluscs. The one about snails in school textbooks by ELIZA RYBSKA and AGNIESZKA CIESZYŃSKA caused a very animated discussion as a result of which we came to a conclusion that the textbooks were hopeless (well, are you surprised?). TEREZA KOŘíNKOVÁ who told us about karyology of Arion did so in Polish, though she is Czech. PIOTR KACZOROWSKI, though he is employed by a pharmacological institution, seems to have switched to malacology and is doing wonderful things about the physiological aspects of snail crawling (poster). The youngest participant, KAMILA ZAJAC, who is just about to get her bachelor's degree, had a very nice presentation about the fauna of the town of Żywiec. Congratulations KAMILA! May you become a great malacologist, and may you get a job. For all the presentations mentioned see Abstracts below.

The programme contained 18 oral presentations and 16 posters. The snail:bivalve ratio was roughly 3.3:1 (4:1 in 2012, 3.47:1 in 2011, 2.33:1 in 2010 and 2.35:1 in 2009, for more ratios from earlier years see earlier volumes of Folia Malacologica), the land:water ratio was 1.9:1 (2.8:1 in 2012, 1.54:1 in 2011, 1.5:1 in 2010 and $0.94: 1$ in 2009). The ratio of one-author presentations to presentations with two or more authors was $0.4: 1 \quad(0.6: 1$ in $2012,0.37: 1$ in $2011,0.85: 1$ in 2010 ), and the ratio of papers/posters presented by girls versus boys was 1.6:1 (1.3:1 in 2012, 1.24:1 in 2011, 1.88:1 in 2010).

The above table contains statistics of the 2007-2013 presentations (many, as usual, assigned to more than one category). The numbers do not show any obvious trend. The number of papers within each discipline just varied from year to year, according to who was present and who had just finished one thing or another. 
If you want to know how the topical structure of our native malacology compares to the world's trends, find the 28th Seminar Report (Folia Malacol. 21: 33-51, 2013: fig. 4) - it has a graph comparing both, and I think this year the graph would be exactly the same. This year some categories in the table were lumped together because some really included very few presentations or no presentations at all in some years. The leading discipline is ecology \& conservation, which I think is in accordance with the trends in the world's malacology. However, I noticed that this year there was a shortage of conservation papers - not shown separately in the table - no conservation grants any more? Or have we exhausted the data mine - the Natura 2000 inventory?

The Wrocław team has bravely volunteered to organise the 30th Seminar which will be held in Łopuszna, which is near Krościenko, the birth place of the Seminars and, in a sense, of the Association. The first reaction of the participants was... guess what? Complaints about the distance. Nevertheless, we hope the attendance will be good. In order to tempt you I'll tell you a few things about Łopuszna. There is a very nice and big hotel, so that we can all stay together. It has a big dining room and a nice place where to have lectures. When and if you want to skip a session, you can go all the way up to Turbacz, a very nice mountain, and the trail starts just next to the hotel. Nearby, there is a fish farm which keeps a fish species most of you haven't seen alive - the huchen, the largest salmonid species. The main excursion will go rafting on the Dunajec River. Getting to Łopuszna is not as hopeless as you might think: enough to get to Kraków or Nowy Targ, and get on a bus or minibus. We might also arrange for a Seminar minibus to collect you from Nowy Targ. As it will be our 30th birthday, we intend to invite some of our neighbours from adjacent and not-so-very adjacent countries.

The abstracts below include all the abstracts from the Abstract Book, most of them translated and some tweaked a bit by the author of this report.

BEATA M. POKRYSZKO

Museum of Natural History, Wrocław University Sienkiewicza 21, 50-335 Wrocław, Poland (e-mail: bepok@biol.uni.wroc.pl)

\section{ABSTRACTS OF THE 28TH POLISH MALACOLOGICAL SEMINAR}

\section{MALACOFAUNA OF CALCAREOUS TUFAS IN SULISŁAWICE NEAR WOLBROM}

\section{Witold PAWEŁ AlEXANDROWICZ}

Katedra Analiz Środowiskowych, Kartografii i

Geologii Gospodarczej, Akademia

Górniczo-Hutnicza, Kraków

Calcareous tufas are deposited in various types of environment, very often as a result of filling of small lakes behind rock, colluvial or travertine barriers in valleys, or sometimes at beaver dams. The tufa outcrops in Sulisławice are located in the Szreniawa Valley between Wolbrom and Miechów (ca. $2 \mathrm{~km}$ W of Wolbrom; $50^{\circ} 22^{\prime} 45^{\prime \prime} \mathrm{N}, 19^{\circ} 50^{\prime} 11^{\prime \prime} \mathrm{E}$ ). They form a terrace of up to $3 \mathrm{~m}$ above the present stream bed, with loose tufas and remains of two travertine barriers. Thirty seven samples from five profiles were analysed. The number of taxa per sample ranged from 7 to 36 , the number of specimens - from 22 to 1,734 . The total number of specimens was 18,366 , representing 50 taxa ( 33 terrestrial snails, 13 aquatic snails, 3 bivalves). Vestigial slug shells were referred to as Limacidae. Malacological analysis employed standard methods. Stratigraphic position of the tufas was based on the composition and structure of the malacofauna and radiocarbon dating of two of the samples. The locality in Sulisławice is a typical example of carbonate sedimentation in lakes formed as a result of stream damming up by travertine barriers. The rich and diverse mollusc fauna provided the basis for conclusions about the development of such lakes. Three development phases were distinguished. The first one reflects the period preceding the formation of the travertine barrier. It holds a characteristic assemblage with dominance of rheophile species, often with admixture of terrestrial snails of damp and/or shaded habitats. The second phase represents deposition of tufas in the lake resulting from formation and growth of the travertine barrier, with a large proportion of species which are characteristic of stagnant waters, of both episodic and permanent character, and with a small proportion of terrestrial forms. Hygrophile, mesophile and shade-loving species dominate there. The periodic appearance of rheophiles may be associated with flood episodes, the increased percentage of terrestrial species - with drying episodes. This phase includes a period of a few hundred to a few thousand years. The last stage represents cutting through the travertine barriers and then through the sediments, and formation of "tufa terraces". Aquatic species disappear to be replaced by poor terrestrial assemblages. The results of studies from numerous localities in the uplands in Poland and elsewhere in Europe confirm the universal character of this model of development of travertine barrier lakes. The between-site differ- 
ences in the composition and structure of the assemblages are mainly due to local conditions.

\section{YEARS OF QUATERNARY MALACOLOGY IN POLAND}

\section{WITOLD PAWE⿺ ALEXANDROWICZ, MAGDALENA GOŁAS-SIARZEWSKA}

Katedra Analiz Środowiskowych, Kartografii i Geologii Gospodarczej, Akademia Górniczo-Hutnicza, Kraków

The studies on subfossil mollusc assemblages in Poland have a long tradition. The first information is found in papers by German geologists, and was mainly prepared for the needs of geological maps. Most of these papers deal with lacustrine chalk localities in Western Pomerania and the Mazurian Lakeland and, to a lesser extent, Lower Silesia. Most descriptions contain only information on the occurrence of mollusc shells; very few contain species lists. First detailed studies on the malacofauna of Quaternary deposits, with attempts at palaeoenvironmental and stratigraphic interpretation, appear between the wars. The studies pertain mainly to lacustrine deposits of the last glaciation. Other papers of that period deal with calcareous tufas, loesses and loess-like deposits, as well as lacustrine deposits representing older interglacials, mainly the Eemian. Till World War II, the occurrence of mollusc shells in Quaternary deposits was recorded from ca. 150 localities. The post-war period witnessed an increase in interest in malacological studies which were used for palaeogeographical reconstructions and stratigraphy. A very fast development of the malacological method started at the end of the 1970s. It was mainly associated with defining and improving the methods which made it possible to use mollusc assemblages to conclude about the habitat and climatic conditions, stratigraphy of the deposits and effects of human interference. The method became recognised as a valuable supplement to lithological, palaeobotanical and archaeological analyses and to radiometric dating. That period involved also a very rapid increase in the number of Quaternary localities, representing various genetic types of deposits and all the important climatic-stratigraphic divisions. The number of localities with the malacofauna studied in detail, with full environmental and stratigraphic interpretation, is several hundred, and most are profiles studied within the last 40 years. The number of localities with mollusc shells is probably around 1,000 or more. Besides, there exist unpublished materials. Considering the number of localities studied, especially those with detailed malacological documentation, Poland is among the leading countries in Europe.

\section{SNAILS OF THE NIDA RIVER (ŚWIĘTOKRZYSKIE VOIVODESHIP)}

\section{AnNA CiePloK, MaŁgorZata STRZELEC}

Katedra Hydrobiologii, Uniwersytet Śląski, Katowice

Our studies were to identify the factors which affected the diversity of gastropod communities in the Nida. Samples were taken monthly (May-September) in 2007-2008 from 10 sites which were representative for the Nida River. The criteria of site selection were: bottom character, flow velocity, depth, degree of shadiness, presence of aquatic vegetation, degree of transformation of river bed and land use within $100 \mathrm{~m}$ from the river. Water samples for physico-chemical analysis were taken in all the sites. Twenty two snail species were recorded, with the greatest diversity in site 7 located in an unregulated section of the river, with sandy-muddy bottom, high content of organic matter in the bottom sediments, sunny water surface and flow velocity not exceeding $15 \mathrm{~cm} / \mathrm{s}$. The smallest diversity was observed in site 4 , in a canalised section of the river, with sandy bottom, small content of organic matter, high degree of shadiness and flow velocity of $32-43 \mathrm{~cm} / \mathrm{s}$. The canalised section of the river ( sites 2-6) showed a small species diversity. The increase in diversity in site 5 , despite the regulation, may have resulted from the bottom character which was different from that in the remaining sites within the human-transformed part of the river. Among the analysed factors, the bottom character and the flow velocity had the greatest effect on the snail diversity and density. Besides, direct effect on the snail density was exerted by electric conductivity of the water, content of $\mathrm{PO}_{4}, \mathrm{O}_{2}$ and organic matter in the bottom sediments. Factors which contributed significantly to the decrease in density were the content of $\mathrm{Fe}$ and $\mathrm{NH}_{3}$ in the water and flow velocity. Positive influence on the snail diversity was exerted by the content of dissolved substances, water oxygenation, while increase in flow velocity had a negative effect on the diversity.

\section{STUDIES ON THE EFFECT OF HERBS ON GASTROPODS}

\section{EWA DANKOWSKA}

Katedra Metod Ochrony Roślin, Uniwersytet Przyrodniczy w Poznaniu, Poznań

Many plants are readily consumed by gastropods. Effects of their feeding on horticultural and agricultural crops decrease the decorative and commercial value of the plants; gastropod pests often destroy the whole crop. They are especially dangerous to young, delicate plants. In conditions of high humidity, optimum temperature and high food availability the gastropods reproduce intensively and often resist at- 
tempts at control. The currently admissible molluscicides are not always effective and may be dangerous to other organisms and environment. Because of the necessity to limit the use of chemical means of plant protection to a minimum, non-chemical substances and non-chemical methods of gastropod control are sought. Plant-derived means of protection are of special interest. Taste and olfactory stimuli are known to play a great part in various inter-specific antagonistic and non-antagonistic interactions. Many plants contain essential oils, protecting the plants against plant-eaters. Results of studies on 23 herbs (spices) with respect to their attractant or deterrent effects on gastropods are presented. Among the studied herbs only seven (cardamom, cumin, pepper, garlic, bay leaf, all-spice) had palatability index below one.

\section{CHINESE CLAM (SINANODONTA WOODIANA) IN THE NATIONAL PARK UJŚCIE WARTY}

\section{JÓZEF DOMAGAŁA, ŁUKASZ CIEŚLIK, MAŁGORZATA PILECKA-RAPACZ}

Katedra Zoologii Ogólnej, Uniwersytet Szczeciński, Szczecin

Sinanodonta woodiana, an alien species in our malacofauna, has been spreading in Poland since the middle 1980s. It was first found in heated canals and lakes of the Konin power plant, then in several other regions of Poland. It was also shown to be able to expand to waters of natural thermal regime. The route of its expansion along the Warta River is interesting. It was first recorded from fish ponds near Sieraków, and then found in the Warta-Gopło canal. In July 2012, S. woodiana was found in the lower Postomia, a left-bank tributary to the lower Warta. The locality held fairly many individuals, since 10 adult specimens were collected during about 3 hours. They were weighed and measured. The shell length ranged from 9.25 to 14.0 $\mathrm{cm}$ (mean $10.6 \mathrm{~cm}$ ), the mass of live specimens - from 78.0 to $198.6 \mathrm{~g}$ (mean $118.9 \mathrm{~g}$ ). Three individuals (2 males, 1 female), shell length $10.1,11.4$ and $14 \mathrm{~cm}$ and mass 98.6, 131.3 and $198.6 \mathrm{~g}$, respectively, were subject to detailed examination. Their gonads were normally developed, according to the season of the year. The female had glochidia in the ctenidia, so the clams reproduced normally. The species is probably continuing to colonise the Warta, starting with the region of Konin. The described locality confirms that the route of the clam's natural expansion runs along the Warta. It is the species' first record within the $\mathrm{Na}$ tional Park Ujście Warty. Anodonta anatina and species of Unio accompanied S. woodiana. This year we are planning to obtain more information on the invader.
HISTOLOGICAL STRUCTURE OF THE GONAD OF THE ZEBRA MUSSEL (DREISSENA POLYMORPHA (PALL.)) FROM THE LOWER ODRA IN THE SPRING-SUMMER PERIOD

\section{JÓZEF DOMAGAŁA, MaŁgOrZata PILECKA-RAPACZ}

Katedra Zoologii Ogólnej, Uniwersytet Szczeciński, Szczecin

After long-term attempts at control of the zebra mussel (Dreissena polymorpha), the species was "rediscovered" in mouths of large Baltic rivers as a means of increasing water transparency. Attempts are now being made at rearing it in special floating rafts. The obtained mass might be converted into fodder, etc. However, little attention is paid to its life cycle which actually determines the effectiveness of practical use of properties of the swimming larvae. Material for this study was collected monthly in 2010 in the Odra at the level of Widuchowa. The mussels were measured and their gonads processed for histological studies; the slides were examined in light microscope Nikon Eclipse 80i to estimate the degree of gonad and oocyte development. Here we discuss only the spring-summer season (April-September). Seventy two adults of shell length $14-20 \mathrm{~mm}$ and mass $0.37-0.89 \mathrm{~g}$ were examined. The sex ratio approached 1:1. Starting with May, the advancement of male gonad development was $3 / 4$ and 4 , then only 4 . Spermatozoa were observed in the gonads during the whole study period. Gonads of spring females were fully developed, containing mature oocytes and oocytes at earlier development stages. From May till August mass maturation of female gonads was observed. At the end of August the gonad follicles were not completely filled with mature oocytes (f4); there were even fewer such oocytes in September. The follicles did not adhere to each other and their lumen was more visible. The gonad activity was ceasing. The gonad activity dynamics in the examined mussels was similar to that in other populations from the lower Odra. However, detailed analysis is required to reveal possible differences in the duration of reproductive activity or quantitative differences. 


\section{ULTRASTRUCTURE OF OOCYTES OF ARION VULGARIS (GASTROPODA, PULMONATA, ARIONIDAE)}

\section{ELŻBIETA GABAŁA ${ }^{1}$, TOMASZ KAŁUSKI ${ }^{1}$, MAŁGORZATA GLAMA ${ }^{2}$}

${ }^{1}$ Centrum Badań Organizmów Kwarantannowych, Inwazyjnych i Genetycznie Zmodyfikowanych, Instytut Ochrony Roślin - Państwowy Instytut Badawczy, Poznań

${ }^{2}$ Wydziałowa Pracownia Mikroskopii Elektronowej i Konfokalnej, Wydział Biologii, Uniwersytet im. Adama Mickiewicza w Poznaniu, Poznań

The gonads of Arion vulgaris were obtained in November from laboratory culture. The maturing oocyte in the gonad is surrounded by a layer of somatic follicular cells. The few microvilli on the oocyte's surface penetrate the space between the oocyte and the apical surface of the follicular cells. Wide invaginations of oolemma are visible between the microvilli. The central part of the oocyte contains a large nucleus of irregular shape. It is surrounded by a porous nuclear membrane. The ooplasm contains numerous ribosomes, cisterns of rough endoplasmic reticulum, well-developed dictyosomes and lipid droplets. The perinuclear zone contains especially numerous accumulations of electron dense granules with heterogeneous contents. Examination of young previtellogenic oocytes suggests that the electron dense granules may originate from autophagous vacuoles in the cytoplasm. Perhaps condensation of the granules' matrix is contributed to by the vesicles containing electron dense material, which detach from the dictyosomes and then merge with the electron dense granules. More peripheral ooplasm contains inclusions of concentric, multi-layered structure. Filiform material forming the inclusions seems to arise in RER cisterns which adjoin the inclusion vesicle membrane. Between the inclusions, mitochondria are more numerous than elsewhere in the ooplasm. The ooplasm just below the oolemma is devoid of large cytoplasmic inclusions, but contains considerable amounts of glycogen and small electron light vesicles. The presence of the vesicles near the ooplasm invaginations may suggest endocytosis which is typical of heterosynthetic vitellogenesis.
HISTOLOGICAL STRUCTURE OF THE FREE OVIDUCT OF RUTHENICA FILOGRANA (GASTROPODA, PULMONATA, CLAUSILIIDAE)

\author{
ELŻBIETA GABAŁA ${ }^{1,2}$, KRYSTYNA SZYBIAK ${ }^{3}$ \\ ${ }^{1}$ Centrum Badań Organizmów Kwarantannowych, \\ Inwazyjnych i Genetycznie Zmodyfikowanych, \\ Instytut Ochrony Roślin - Państwowy Instytut \\ Badawczy, Poznań \\ ${ }^{2}$ Zakład Biologii Komórki, Instytut Biologii \\ Eksperymentalnej, Uniwersytet im. Adama \\ Mickiewicza w Poznaniu, Poznań \\ ${ }^{3}$ Zakład Zoologii Ogólnej, Instytut Biologii \\ Środowiska, Uniwersytet im. Adama Mickiewicza \\ w Poznaniu, Poznań
}

The free oviduct is a section of the snail's female reproductive system, from the point of departure of vas deferens from spermoviduct to the outlet to vagina. In $R$. filograna the free oviduct has two morphologically different sections: proximal and distal (proper) oviduct. The proximal oviduct is a continuation of the two spermoviduct grooves: allospermiduct and egg channel. As in the spermoviduct, the allospermiduct is a system of canaliculi built of subepithelial eosinophilic secretory cells and of ciliated epithelial cells with microvilli. The main components of the egg channel wall are mucus cells overlain by epithelial cells with a dense brush border and long ciliae. Further along the oviduct the two grooves change rather abruptly: the allospermiduct undergoes drastic reduction, the eosinophilic and mucus cells disappear, while the epithelial cells become high. Then the fold separating the two grooves disappears. The wall of distal oviduct is folded, due to the presence of a thick layer of circular muscles. The wide folds are covered by cylindrical epithelium with a brush border and disappearing ciliae. Single mucus cells, scattered in connective tissue, open among the epithelial cells. Characteristic features of the vagina start appearing at some distance from the spermatheca duct outlet. In $R$. filograna the free oviduct is not a duct of a uniform histological structure over its whole length, and the typical vaginal histological features are not compatible with the anatomical beginning of vagina. 
MORPHOLOGICAL CHARACTERS

OF COPULATORY ORGANS AND EGGS OF ARION RUFUS AND A. LUSITANICUS

\author{
MONIKA JASKULSKA ${ }^{1}$, MAGDALENA GAWLAK ${ }^{2}$, \\ JAN KOZŁOWSKI ${ }^{1}$ \\ ${ }^{1}$ Zakład Zoologii, Instytut Ochrony Roślin - \\ Państwowy Instytut Badawczy, Poznań \\ ${ }^{2}$ Centrum Badań Organizmów Kwarantannowych, \\ Inwazyjnych i Genetycznie Zmodyfikowanych, \\ Instytut Ochrony Roślin - Państwowy Instytut \\ Badawczy, Poznań
}

Arion lusitanicus Mabille, 1868 and A. rufus Linnaeus, 1758 are polyphagous and seriously damage many kinds of crops. The size of damage depends mainly on the abundance of the slugs and their activity which is determined by weather, soil and cultivation conditions. Identification of the two species is very important from the point of view of both science and plant protection practice. In order to take proper control measures it is necessary to identify the pest species which is especially difficult in the case of juveniles. Advancement of microscope techniques makes it possible to study their morphology and anatomy in great detail, which may facilitate quick, effective and relatively cheap identification. The Institute of Plant Protection started a project aimed at finding identification-useful morphological characters of A. lusitanicus and A. rufus. The structure of selected copulatory organs and eggs of the two species was analysed using stereomicroscope and scanning electron microscope. Spermatophore shape and size were observed and eggs were measured under stereomicroscope. Spermatophore micromorphology and structure of the inner and outer side of egg envelopes were analysed in SEM. The spermatophores of $A$. lusitanicus and A. rufus differ in the size and shape of denticles which is visible under stereomicroscope, but do not differ in the microstructure of their surface. SEM analysis of the egg envelopes revealed no differences between the species, but the inner and outer side of the envelopes differed in their structure.

\section{THE EFFECT OF THE PARASITIC NEMATODE PHASMARHABDITIS HERMAPHRODITA} ON THE VIABILITY OF JUVENILE SLUGS

\section{MONIKA JASKULSKA, JAN KOZŁOWSKI, MARIA KOZŁOWSKA}

Zakład Zoologii, Instytut Ochrony Roślin Państwowy Instytut Badawczy, Poznań

Some slugs of the genera Arion and Deroceras do considerable damage to crops and plant communities. They often occur in masses and damage various agricultural, horticultural and orchard crops causing considerable economic losses. Chemical slug control using granulated molluscicides (methiocarb and methaldehyde) sometimes has an adverse effect on the non-pest fauna while its effectiveness is often insufficient. Environment-safe biological methods of control provide an alternative. One of such methods is using commercial Nemaslug, containing the parasitic nematode Phasmarhabditis hermaphrodita (Schneider), which carries a toxic bacterium Moraxela osloensis, causing slug mortality and/or limiting slug feeding. It is used to control various species, but its effectiveness varies and depends on many factors. This pertains mainly to large slugs, such as Arion lusitanicus and A. rufus; their juveniles are the most sensitive to infection with $P$. hermaphrodita. Some authors maintain that $P$. hermaphrodita does not limit the abundance of these slugs but inhibits their feeding. A different effect of $P$. hermaphrodita was observed in the case of Deroceras reticulatum, which is destroyed by the nematode. Our studies aimed at assessing the effect of $P$. hermaphrodita on the mortality of various weight classes of juvenile A. lusitanicus, A. rufus and D. reticulatum. In the laboratory, individuals of each species of various weight classes were infected with two doses of $P$. hermaphrodita (15 and 30 nematodes $/ \mathrm{cm}^{2}$ ). After four days single slugs were transferred to Petri dishes and during the next 10 days given food in the form of circles of Pekingese cabbage. Infection symptoms and viability of the slugs were controlled daily. The mortality of juveniles ( $<1.0 \mathrm{~g}$ ) of D. reticulatum, $A$. lusitanicus and A. rufus of all weight classes for both doses was $43.3 \%, 7.5 \%$ and $27.5 \%$, respectively. The remaining infected slugs survived till day 16 after the nematode application, but some showed a considerably limited feeding activity.

\section{INTENSITY OF STUDIES AND ASSESSMENT OF SPECIES DIVERSITY: MOLLUSCS \\ OF FLOODPLAIN WATER BODIES OF THE LOWER BUG RIVER}

EWA JURKIEWICZ-KARNKOWSKA

Instytut Biologii, Uniwersytet

Przyrodniczo-Humanistyczny w Siedlcach

Assessment of biodiversity in various habitats and comparisons among habitats require complete species lists. Log-normal distribution curves provide a good way of testing the completeness and of standardising the comparisons; the number of species is the dependent variable while the intensity of studies (number of samples, number of individuals, surface area, time), is the independent variable. Such curves reach an asymptote when the probability of finding yet another species is nearly none. Distribution curves are also useful to estimate the number of samples which is necessary to obtain a reliable assessment of 
species diversity. Aquatic habitats of the floodplain of the lower Bug River show a high diversity, temporal variation of habitats and great species richness of molluscs. In earlier studies obtaining a sufficiently complete species list from the area required sampling of more than 60 (up to 70) water bodies (1-3 samples per water body, depending on its size). The aim of this study was to assess the completeness of mollusc species list of selected water bodies of the lower Bug floodplain, and to specify the minimum number of samples which would ensure a satisfactory effectiveness of surveys in its periodic and permanent water bodies. The relationship between intensity of studies and species diversity, as well as variation in the dominance structure, were analysed. Molluscs were sampled from May to September of 2005-2012 from 5 permanent and 5 periodic water bodies. Each water body was sampled 4-6 times, taking 1 to 6 samples, depending on the size and habitat diversity. The sampling continued till nearly complete species lists were produced (at least $90 \%$ potential species richness as estimated using Chao2). Their completeness was estimated based on accumulation curves generated with EstimateS. Fifty seven mollusc species were recorded from the ten sampled water bodies, that is all the species recorded during the extensive studies of 176 water bodies of the lower Bug valley. The five permanent water bodies held 51 species, the five periodic water bodies - 35 species ( 6 found only in such water bodies). The number of species per water body ranged from 8 to 20 (15-20 in the permanent and 8-14 in the periodic water bodies). The total number of species in all samples from the water body was 23-35 in the permanent and 15-21 in the periodic water bodies. The mean number of species per sample was 6-12 (7-10 in the permanent and 6-12 in the periodic water bodies; no statistically significant differences). The species composition, species richness and dominance structure of the malacocoenoses varied through time and among the water bodies. Some species which were recorded only in 1-2 samples in a water body were observed to form a rather high proportion in the malacocoenoses. These were rare and endangered species or species typical of lotic habitats. The number of random samples necessary to obtain an over $90 \%$ complete species list ranged from 13 to 17 for the permanent water bodies. Fewer samples, 6-10, were needed in the case of periodic water bodies which showed a smaller variation in the composition of their malacocoenoses and a greater uniformity of their habitats. Representative data (at least $70 \%$ potential species richness), for example for the purpose of monitoring, can be derived from a much smaller number of random samples: 4-6 for the permanent and 2-3 for the periodic water bodies.

\section{ALPHA-ADRENERGIC EFFECT ON THE MOTOR ACTIVITY OF EPITHELIUM OF ACHATINA FULICA}

\section{PIOTR KACZOROWSKI, WOJCIECH PAWŁOWICZ, JOANNA STEMPIEŃ, MONIKA LUTOWSKA, TOMASZ TYRAKOWSKI}

Katedra i Zakład Patobiochemii i Chemii Klinicznej, Uniwersytet Mikołaja Kopernika, Collegium

Medicum w Bydgoszczy

Motor activity of epithelium involves changes in the epithelium's folding on the surface of snail's sole. The forces causing snail movement act through momentarily immobile sole sections. The forces are muscle-generated. The role of sole's epithelium consists in moving this part of the body cover during motion which can be observed and registered (CCD camera coupled with a computer) during spontaneous, rectilinear movement of the snail on a horizontal glass surface, as series of moving stripes (sole waves). We analysed the following parameters: snail's speed, sole length $(\mathrm{lg})$, number of sole waves (nw), length of sole wave (lw), length of space between waves, ratio of sole wave surface to sole surface $(\mathrm{lw} \cdot \mathrm{nw} / \mathrm{lg})$, wave frequency, distance covered per sole wave (shw) and folding value $(\mathrm{shw} / \mathrm{lw})$ in control conditions and after injection of clonidine (agonist of $\alpha_{2}$-adrenergic receptor) or phentolamine (non-specific antagonist of $\alpha$-adrenergic receptor), at doses of 10 and $0.1 \mu \mathrm{g} / \mathrm{g}$ body mass in the postero-dorsal part of the foot; their effect was recorded during two hours. Statistical analysis used U Mann-Whitney test $(\mathrm{p}<0.05)$. Statistically significant differences between the control and experimental groups pertained to the sole wave length, wave frequency and folding value. Clonidine and phentolamine changed the motor activity of the sole epithelium. This shows that ganglionic and/or muscular and epithelial cells of terrestrial snails bear a-adrenergic receptors which bind clonidine and phentolamine and have an effect on the regulation of the epithelium's motor activity. 
GENETIC POLYMORPHISM OF SELECTED LOCAL POPULATIONS OF THE ROMAN SNAIL (HELIX POMATIA L.) IN POLAND

TOMASZ KAŁUSKI ${ }^{1}$, MARIANNA SOROKA ${ }^{2}$, RENATA JARZĄB ${ }^{2}$, TOMASZ KALINOWSKI ${ }^{3}$, ANNA JANKOWIAK ${ }^{3}$, ELIZA RYBSKA ${ }^{4}$, JERZY BŁOSZYK ${ }^{3}$

${ }^{1}$ Centrum Badań Organizmów Kwarantannowych, Inwazyjnych i Genetycznie Zmodyfikowanych, Instytut Ochrony Roślin - Państwowy Instytut Badawczy, Poznań

${ }^{2}$ Katedra Genetyki, Uniwersytet Szczeciński, Szczecin ${ }^{3}$ Zakład Zoologii Ogólnej, Instytut Biologii Środowiska, Uniwersytet im. Adama Mickiewicza w Poznaniu, Poznań

${ }^{4}$ Wydziałowa Pracownia Dydaktyki Przyrody

i Biologii, Wydział Biologii, Uniwersytet im. Adama

Mickiewicza w Poznaniu, Poznań

The studies, aimed at estimating the level of genetic variation and diversity in populations of Helix pomatia (Linnaeus, 1758), included 25 sites in central Poland. Sequential analyses of the mitochondrial gene $\operatorname{cox} 1$ showed the presence of 12 different genotypes of mean length of 651 base pairs among the examined 121 individuals. Most populations (56\%) were polymorphic and most often had two different genotypes, only five populations had three genotypes each. The mean diversity of all genotypes was $0.7 \%$, particular genotypes differed by 0.2 to $1.3 \%$. A total of 16 polymorphic loci were identified, where no mutation caused changes in the encoded amino-acid. One genotype (frequency $10 \%$ in Poland) was identical with a genotype from France, accessible in GenBank (accession number JX911304). The Polish genotypes of $H$. pomatia showed a large genetic difference, at the level of $0.8-1.6 \%$, compared to a specimen from the Caucasus (Georgia, accession number GU784807).

\section{KARYOLOGICAL CHARACTERISTICS OF SOME LARGE ARION SPECIES}

\section{TEREZA KOŘÍNKOVÁ ${ }^{1,2}$ \\ ${ }^{1}$ Senckenberg Museum of Natural History Görlitz, Germany \\ ${ }^{2}$ Institute of Animal Physiology and Genetics, Liběchov, Czech Republic}

Although many gastropod lineages are conservative in their karyotypes at the generic, or even family, level, some Arion species have been reported to differ in chromosome numbers. Cytogenetic data thus might contribute to solving taxonomic difficulties, for instance within the "large Arion" (subgenus Arion s. str.), which include $A$. rufus, A. ater, the invasive species A. vulgaris (previously confused with $A$. lusitanicus) and several other taxa. I have investigated the chromosome morphology, the chromosomal localisation of selected nuclear genes and the possible presence of species-specific chromosome regions in several species of large Arion. The native Central European species $A$. rufus and the invasive A. vulgaris exhibited the same karyological characteristics: 26 chromosome pairs (13 meta- or submetacentric, 13 subtelo-acrocentric) of gradually decreasing length, the longest pair being metacentric and about five times longer than the shortest. The chromosome numbers agree with those reported for both species by other authors. Fluorescence in-situ hybridisation revealed two rDNA clusters situated near the centromeres of two chromosome pairs: genes of the $45 \mathrm{~S}$ unit (18S and $28 \mathrm{~S}$ rDNA) are localised on a large acrocentric chromosome pair, while $5 \mathrm{~S}$ occurs on a middle-sized metacentric pair. The same characteristics were shared by a species of large Arion from northern Spain. The close similarity between the karyotypes of the invasive species and its indigenous counterpart led me to search for species-specific chromosomal regions using comparative genome hybridisation. This further confirmed the lack of substantial differences between the karyotypes, suggesting that the species may well have the potential to produce fertile hybrids.

\section{FOOD PREFERENCES OF ARION LUSITANICUS \\ MABILLE TO SELECTED SPECIES \\ AND VARIETIES OF PLANTS}

\section{JAN KOZŁOWSKI, MONIKA JASKULSKA}

Zakład Zoologii, Instytut Ochrony Roślin -

Państwowy Instytut Badawczy, Poznań

Gastropods display strong food preferences, and thus the degree of damage to different plant species may vary widely. The fact can be used to protect cultivated plants against gastropod pests. In recent years leguminous and papillionaceous crops have gained in economic importance, but still protection programmes for these plants are insufficient. The situation results, among other things, from the lack of detailed data on the danger posed by various agrophages, including gastropods. We studied the extent of damage to 15 plant species by A. lusitanicus in the laboratory. In choice tests we used five sets, each of six species or varieties of plants. The plants used were at the stage of 4-6 leaves; the slugs had mean mass of $1.39 \mathrm{~g}$. The data were statistically analysed using variance analysis and Tukey test, significance level 0.05 . The most sensitive plants were chicory var. Monitor and yellow lupin var. Dukat. The least and slowest damaged were pea (Telefon), common pea (Milwa), sorghum (Sucrosorgo) and vetch (Hanka). The damage to the least sensitive plants after seven days was by ca. $50 \%$ smaller than that to the sensitive plants. 
LIFE CYCLE OF VALLONIA COSTATA

(O. F. MÜLLER, 1774) (GASTROPODA: PULMONATA: VALLONIIDAE) IN THE LABORATORY

\section{ELŻBIETA KUŹNIK-KOWALSKA ${ }^{1}$, MAŁgORZATA PROĆKÓW ${ }^{2}$}

${ }^{1}$ Zakład Systematyki i Ekologii Bezkręgowców, Instytut Biologii, Uniwersytet Przyrodniczy we Wrocławiu, Wrocław

${ }^{2}$ Muzeum Przyrodnicze, Uniwersytet Wrocławski, Wrocław

Vallonia costata inhabits vast areas of Palaearctic, from northern Africa to Kashmir and Siberia; it is also found in the Canary Islands, and in Norway its range extends to $70^{\circ} \mathrm{N}$. In Poland, it is found in the whole country, very common in the lowlands and less so in the mountains. Its main habitats are dry, grassy and open areas, especially on calcareous substrata, meadows, stone walls, screes, less often it is found in scrub and damp habitats. Our studies aimed at ascertaining life cycle parameters of $V$. costata in laboratory conditions. The material was collected in Kamienna Góra, ruins of castle Grodztwo $\left(50^{\circ} 47.449^{\prime} \mathrm{N}, 16^{\circ} 02.160^{\prime} \mathrm{E}\right.$, $440 \mathrm{~m}$ a.s.l.). The snails were kept in Petri dishes in a climatic chamber, at constant temperature (day $18^{\circ} \mathrm{C}$, night $\left.12^{\circ} \mathrm{C}\right)$, humidity $(80 \%)$ and lighting (12:12). $\mathrm{V}$. costata laid eggs singly, on the tissue paper lining the dish, on lettuce leaves or leaf litter fragments. Individuals kept in pairs and groups and those kept singly produced eggs. Newly laid eggs were calcified, slightly ellipsoidal and flattened, milky white, mean size 0.69 $\times 0.67 \times 0.54 \mathrm{~mm}$. Eggs were laid throughout the year. The number of eggs per individual lifetime was 1-55 (mean 22). The hatchlings had translucent shells and bodies, the shells had 1.0-1.75 whorl. Morphological (lip completion) and sexual (first egg) maturity was reached at 3.25-3.5 whorls. Growth progressed in two phases - I. fast: from 1.5 to 3.0 whorls; II. slow: after reaching 3.0 whorls. The life span was at least 20 months.

\section{WHAT DOES VALLONIA DO WITH ITS EGGS?}

\section{ELŻBIETA KUŹNIK-KOWALSKA ${ }^{1}$,} MAŁgORZATA PROĆKÓW² ${ }^{2}$ ElżBIETA PląsKOWSKA ${ }^{3}$

1'Zakład Systematyki i Ekologii Bezkręgowców, Instytut Biologii, Uniwersytet Przyrodniczy we Wrocławiu, Wrocław

${ }^{2}$ Muzeum Przyrodnicze, Uniwersytet Wrocławski, Wrocław

${ }^{3}$ Katedra Ochrony Roślin, Uniwersytet Przyrodniczy we Wrocławiu, Wrocław

Juveniles and adults of both Vallonia pulchella (O. F. Müller, 1774) and V. costata (O. F. Müller, 1774) show a particular behaviour towards eggs. Holding and turning the egg with its foot, the snail moves its head and "licks" the egg with its radula, as if feeding. Examination of the egg surface revealed the presence of a predatory nematophagous fungus Arthrobotrys oligospora Fresen, 1850. The fungus is common in the soil and its life style varies: it is not only a nematode pathogen, but can as well be saprotrophic and infect plant roots; in favourable conditions it is capable of mycoparasitism. The fungus hyphae were found to grow through the calcified egg shell, and the snail behaviour was probably associated with their removal. The significance of the behaviour remains unclear: the fungus may be a food source and/or the behaviour may be a form of parental care. In the latter case it would be necessary for the snail to be able to recognise its own eggs, but no such ability has been found in terrestrial snails.

\section{THE EFFECT OF INTRODUCTION OF THE ROMAN SNAIL (HELIX POMATIA L.) AGED 1+ INTO NATURAL HABITAT, IN THE SECOND YEAR OF STUDIES. PART II}

\section{MAciej LigASZEWSKI, PRZEMYSŁAW POL}

Instytut Zootechniki - Państwowy Instytut Badawczy, Kraków

The project aimed at establishing near Cracow (Poland) and monitoring three experimental populations of the Roman snail, according to the following three forms of active species protection: 1 . Active protection in a replacement locality of naturalised population; the population was a result of introduction of farm-bred snails aged 1+ into a habitat which previously had no natural population (Będkowice); 2. Active protection in a replacement locality through reinforcing the local population with farm-bred snails aged 1+ (Mydlniki-Wapiennik); 3. Active protection through reinforcing the local population with snails aged 1+ obtained from adults from the same population (Balice). Three thousand marked snails were released in each locality. Sampling consisted in collecting, during one person-hour, from an area of $500 \mathrm{~m}^{2}$, once per season, in optimum weather conditions. Already in the first year of observations it was found that the introduction of farm-bred $H$. pomatia aged $1+$ had a significant effect on the structure and density of natural populations. The growth rate of such snails was similar to that of the snails from the natural population. The growth was the fastest in the site sown with fodder plants, slower in the park site with access to herbaceous plants and compost, the slowest in the forest site. The differences in the shell diameter and body mass were highly statistically significant $(\mathrm{P}<0.01)$. In 2012 the farm-bred released snails were in age class $2+$. In the first year the percentage of 
farm-bred snails in the respective age classes of the natural populations in Balice and Mydlniki was $52.7 \%$ and $51.1 \%$, in the second year it was $49.1 \%$ and 48.9 $\%$, respectively. In the second year the total proportion of mature farm-bred snails aged 2+ was $24.1 \%$ and $46.5 \%$, respectively, and that of snails from the natural populations, of the same age class, was $26.8 \%$ and $24.4 \%$. In the site devoid of natural population (Bedkowice) the proportion of mature snails in the second year was $51.8 \%$. Thirteen months after the introduction of the farm-bred snails aged 1+ into natural localities, their presence was still showing a great effect on the structure of the local populations. The introduction also allowed to create a naturalised population composed of an abundant cohort of mature farm-bred snails which laid eggs in their second season in the natural locality (Będkowice).

\section{POPULATION STRUCTURE OF BIVALVES FROM HEATED WATERS}

\section{ANNA MARIA ŁABECKA ${ }^{1 *, 2}$, JÓZEF DOMAGAŁA ${ }^{2}$}

${ }^{1}$ Instytut Nauk o Środowisku, Uniwersytet Jagielloński, Kraków (*present address)

${ }^{2}$ Katedra Zoologii Ogólnej, Uniwersytet Szczeciński, Szczecin

The interest in the effects of introducing heated water into natural environment has been growing since the advent of water cooling systems in power plants. Such water is of economic importance (fish culture) and provides an opportunity to study anthropogenic ecosystems. The "local heat islands", such as discharge canals of cooling waters, provide a favourable habitat for thermophilous organisms from remote regions of the world. The studies were conducted in the heated waters of the Dolna Odra power plant in the summers of 2005 and 2007. On each sampling, water temperature, oxygen content, $\mathrm{pH}$ and conductivity were measured. Bottom samples were taken from the discharge canal and subjected to granulometric analysis. Random mollusc samples were taken with a $50 \times 50 \mathrm{~cm}$ frame. Besides the native bivalve species (Unio tumidus, U. pictorum, Anodonta anatina, A. cygnea), Dreissena polymorpha and three species new to the Polish fauna were recorded. These were the Asian Sinanodonta woodiana, Corbicula fluminea and C. fluminalis. The molluscs were weighted and their shells measured. The individuals were sexed and the females checked for the presence of eggs or larvae. We are planning to characterise the population structure of the alien species, their density, biomass, dominance and sex ratio. The studies were financed by the Faculty of Biology and Earth Sciences, Jagiellonian University, grant no. DS/MND/WBiNoZ/INoŚ/2/2012.

\section{HABITAT PREFERENCES OF FOREST CLAUSILIIDS}

\section{MAGDALENA MARZEC}

Muzeum Przyrodnicze, Uniwersytet Wrocławski, Wrocław

Microhabitat preferences of clausiliids were studied in Romincka Forest (NE Poland) in 12 oak-hornbeam sampling plots of $100 \mathrm{~m}^{2}$ each. Each plot was controlled twice: autumn - October 2010 and summer - June 2011. The clausiliids were collected by eye, and ca. 101 of litter were sorted on site. Snails from each microhabitat were collected separately; the parameters recorded were circumference at the height of $1.30 \mathrm{~m}$ for live trees; type of timber (log, branch, fragment, bark), position (laying, standing, hanging or leaning against a live tree), thickness, timber diameter, decomposition class ( 1 - fresh timber to 5 - rot) for dead timber; thickness, main component, presence of additional components, $\mathrm{pH}$ for litter. The 10 plots yielded 945 individuals representing 8 species: Cochlodina laminata (237 specimens - 10 plots), Clausilia cruciata (164-7), Macrogastra plicatula (161 8), Clausilia dubia (112-6), Bulgarica cana (98 - 7), Laciniaria plicata (91 - 4), Macrogastra ventricosa (747) and Macrogastra latestriata $(8-3)$. The clausiliids occurred in three microhabitats: dead timber, live trees and litter. No species was exclusively associated with one habitat. Most species preferred dead timber, except $C$. cruciata and B. cana, which were most numerous on live tree trunks. None of the species preferred litter. The species varied in their preferences to the degree of timber decomposition, but none was limited to one decomposition stage. The most abundant species on dead timber of the first degree of decomposition were C. cruciata, C. dubia and B. cana, the second degree of decomposition - C. laminata, the third degree - M. plicatula and L. plicata. Only one of the examined trunks was filled with rot (fifth degree of decomposition) and held $M$. ventricosa and $M$. latestriata. Most species occurred on dead timber of varied thickness. Only C. dubia was never found on timber exceeding $40 \mathrm{~cm}$ diameter, though such timber was present in the plots where the species occurred. Species preferring thick timber (diameter $>40$ $\mathrm{cm}$ ) were $M$. plicatula and L. plicata; species preferring thin timber (diameter $<20 \mathrm{~cm}$ ) were $C$. dubia and $C$. cruciata. Horizontal timber was the preferred habitat of M. plicatula and L. plicata, standing timber - of $C$. dubia, hanging logs - of $C$. cruciata. The remaining species showed no significant preference to any particular position of timber. The total number of clausiliid individuals increased with the quantity of dead timber in the plot $(\mathrm{r}=0.8, \mathrm{p}<0.01 \mathrm{n}=10$ plots $)$. However, considering individual species, only the numbers of $M$. ventricosa and $C$. cruciata were correlated with the quantity of timber. No correlation was 
found between the clausiliid species richness and the quantity of dead timber $(r=0.47 ; p=0.16)$. All the clausiliid species which preferred live trees had access to lime, ash, hornbeam, hazel, oak, birch, rowan and spruce. C. cruciata and B. cana were the most abundant on hazel and somewhat less so on hornbeam. $C$. laminata preferred hazel, with similar numbers occurring on the other tree species except oak which it avoided. C. dubia equally readily stayed on lime, ash and hazel. No special preferences were found as to the diameter of live trees. The clausiliids on the whole utilised all available microhabitats, and the preferences were expressed only as differences in the frequency of occurrence. The study was sponsored by a grant from the Malacological Society of London.

TOMASZ UMIŃSKI'S MALACOLOGICAL COLLECTION AT THE MUSEUM

AND INSTITUTE OF ZOOLOGY, POLISH ACADEMY OF SCIENCES, WARSAW

\section{DOMINIKA MIERZWA-SZYMKOWIAK}

Muzeum i Instytut Zoologii, Polska Akademia Nauk, Warszawa

The history of zoological collections of the $\mathrm{Mu}$ seum and Institute of Zoology, Polish Academy of Sciences (MiIZ PAN), Warsaw, dates back to the beginning of the 19th c., when the Zoological Cabinet was established at Warsaw University. During the more than 190 years of activity of the MiIZ PAN many outstanding scientists contributed to building up scientific zoological collections. The malacological collection donated to the Museum by Professor Tomasz Umiński (for many years employed at Warsaw University) is an example of continuation of this beautiful tradition. The unique collections which at present include more than 800 thousand specimens from various parts of the world became enriched with new materials. The existing collections include, among others, those donated by Władysław Emanuel Lubomirski (materials from South America collected by Konstanty Jelski and Jan Sztolcman), Osborn Retowski (Crimea, Caucasus and Asia Minor, and specimens from all over the world obtained through exchange), Antoni Wagner (Austria and the Balkan countries), Władysław Poliński and Stanisław Feliksiak (Poland) and Adolf Riedel (Europe, Africa and Asia). Professor Tomasz Umiński's collection includes more than 130 species of terrestrial snails from the families Bradybaenidae, Chondrinidae, Clausiliidae, Cochlicopidae, Ellobiidae, Endodontidae, Enidae, Euconulidae, Gastrodontidae, Helicidae, Orculidae, Pyramidulidae, Succineidae, Valloniidae, Vertiginidae, Vitrinidae and Zonitidae. The specimens were mainly collected in Poland and Sweden in 1911-2009 by researchers and collectors. The collec- tion includes dry material (shells), soft parts with shells, kept in preserving fluids, and microscope slides. Tomasz Umiński's field notes, electronically available, form an integral part of the collection. The specimens donated by Tomasz Umiński constitute a valuable scientific and teaching material.

\section{MOLECULAR ASPECTS OF TORPOR OF TERRESTRIAL SNAILS}

\section{ANNA NOWAKOWSKA}

Zakład Fizjologii Zwierząt, Uniwersytet Mikołaja Kopernika, Toruń

Terrestrial snails subject to diurnal and seasonal changes of temperature and humidity show many behavioural, morphological, physiological and biochemical adaptations which enable them to survive the environmental changes. One of the adaptations is torpor when the animal shows no motor activity, and its metabolic processes are slowed down. Surviving torpor is possible due to a universal defensive mechanism at molecular level: change in gene expression and synthesis of heat shock proteins (HSP), and other stress-induced proteins. In physiological conditions HSP in cells are responsible for stabilising other proteins, their distribution, secretion, life span and degradation. Besides, HSP are closely associated with protecting the organism against various stress factors, such as changes in temperature, oxygen availability or photoperiod. HSP protect cells from the effect of heat and other factors, such as chemical compounds, heavy metals, oxidation stress, dehydration. It seems that the tolerance to all the above factors depends on the synthesis of HSP. There is evidence that the expression of HSP increases during aestivation in various gastropod species, suggesting that the regulation is a part of the mechanism stabilising proteins and contributes to long-term stability of the metabolism during aestivation. The role of HSP associated with the annual cycle of activity/aestivation has been described for Otala lactea and Sphincterochila sp. Furthermore, it appears that the adaptation of gastropods to various habitat conditions is a result of development of distinct strategies of HSP expression which suggests that also gastropod distribution results from their tolerance to stress factors and from their ability to synthesise HSP. 
CO-OCCURRENCE OF MONACHA CARTUSIANA AND MONACHA CLAUSTRALIS IN POLAND AND THE CZECH REPUBLIC

\author{
JOANNA R. PIEŃKOWSKA ${ }^{1}$, MARCIN GÓRKA², \\ ANDRZEJ LESICKI ${ }^{1}$ \\ ${ }^{1}$ Zakład Biologii Komórki, Wydział Biologii, \\ Uniwersytet im. Adama Mickiewicza \\ w Poznaniu, Poznań \\ ${ }^{2}$ Instytut Geologii Podstawowej, Uniwersytet \\ Warszawski, Warszawa
}

Snails of the genus Monacha Fitzinger, 1833 are numerously represented in Europe. According to the literature, Europe holds nearly 40 species. Only one of them was previously recorded from Poland ( $M$. cartusiana), and two from the Czech Republic ( $M$. cartusiana and M. cantiana). Our studies, using anatomical and molecular characters, revealed the occurrence of yet another species in both Poland and the Czech Republic - M. claustralis. In the Czech Republic it was probably this species that was misidentified as M. cantiana. Till now several localities of the two species were found in Poland; these extend the European range toward north-east. The localities of $M$. cartusiana which we verified molecularly are situated in southern Poland and in the Czech Republic. $M$. claustralis occurs mainly in western, central and northern Poland, and also in Prague. Molecular analysis of specimens of both species collected in Poland (8 populations) and in the Czech Republic (4 populations) revealed three localities where they co-occurred. One was situated in Wietrznia near Kielce, the remaining two - within the city of Prague. M. cartusiana and $M$. claustralis are very similar in their shell characters. They differ in details of structure of their reproductive systems and in molecular characters. Our results indicate that their distribution ranges overlap partly, so that they co-occur in some sites. Their identification should be approached with caution.

\section{THE JOINT EFFECT OF IONIZING RADIATION AND HEAVY METAL IONS ON THE REPRODUCTION OF LYMNAEA STAGNALIS}

\section{T. V. Pinkina, A. A. Pinkin, T. M. Chernushova}

Zhytomyr National Agroecological University, Zhytomyr, Ukraine

Though separately small radiation doses and low concentrations of heavy metals may hardly show a harmful effect on aquatic organisms, they often exert a synergistic effect. Our study was to check if radiation complicated or enhanced the effect of heavy metals on mollusc reproduction. Molluscs dominate in bottom communities of many water bodies; being capable of accumulating heavy metals and radio-nuclides, they play a key role in biological migration of these substances in aquatic ecosystems. Lymnaea stagnalis Linnaeus, average shell height $39.5 \pm 1.1 \mathrm{~mm}$, from the Loznitsa River (region affected by the Chornobyl accident) and from the unpolluted Teteriv River were acclimated to laboratory conditions during two days; then they were exposed to heavy metal ions at various concentrations. The heavy metal concentrations used in the experiment caused significant disturbances of reproduction of the snails from the radioactive zone. During 70 days of the experiment, control animals laid 1.5 times more syncapsules than those from the contaminated water body $(\mathrm{P}<0.05)$. The snails from the radioactive zone, exposed to solutions of $\mathrm{Zn}^{2+}$, $\mathrm{Co}^{2+}, \mathrm{Mn}^{2+}$ of all the concentrations applied, laid 1.8-2.0 times fewer sycapsules $(\mathrm{P}<0.05)$. Only subliminal concentrations of $\mathrm{Cd}^{2+}$ failed to produce a statistically significant difference. The fewest syncapsules $(12 \pm 1)$ were produced under the effect of subliminal concentration of $\mathrm{Zn}^{2+}$, and of the chronic lethal concentration of $\mathrm{Co}^{2+}(9 \pm 1)$. The maximum number of syncapsules was produced under the effect of $\mathrm{Ni}^{2+}$ at all concentrations $(\mathrm{P}<0.05)$, but it was still smaller than in the pure-water group. During 70 days of the experiment snails from the Loznitsa River laid on average $50 \pm 5$ syncapsules ( 1.7 times less than the snails from the Teteriv River, 84 \pm 7 ). The length of syncapsules laid by the snails from the radioactive zone varied insignificantly, but most were smaller than those produced by the pure-water group. A similar regularity was observed for the two groups not exposed to heavy metals (Teteriv River - 33.75 \pm 0.64 mm; Loznitsa River - 32.86 $\pm 0.92 \mathrm{~mm})$. The syncapsules produced by the snails from the radioactive zone showed the same structural anomalies as those laid by the snails affected only by the heavy metal ions, but nearly all the anomalies were 1.5 times more frequent. The number of egg capsules per syncapsule and the hatching success were smaller in the group from the Loznitsa than in that from the Teteriv. The number of egg capsules per syncapsule of the snails from the radioactive zone exposed to heavy metal ions decreased $1.5-2.3$ times $(\mathrm{P}<0.05)$. The mean number of egg capsules per syncapsule and the hatching success of the snails from the radioactive zone were significantly smaller, compared to the snails from the Teteriv River for the groups not exposed to heavy metal ions: egg capsules per syncapsule $94.88 \pm 4.7$ for the Loznitsa River and $106.6 \pm 4.37$ for the Teteriv River; the respective values of hatching success $-68.9 \pm 3.67 \%$ and $87.9 \pm 1.35 \%$ ) $(\mathrm{P}<0.05)$. 


\section{BANAT - A PART OF THE CARPATHIANS?}

\section{BEATA M. POKRYSZKO ${ }^{1}$, ROBERT A. D. CAMERON ${ }^{2}$, VOICHITA GHEOCA ${ }^{3}$}

${ }^{1}$ Muzeum Przyrodnicze, Uniwersytet Wrocławski, Wrocław

${ }^{2}$ Department of Animal and Plant Sciences, University of Sheffield, Sheffield, UK

${ }^{3}$ Department of Zoology, Lucian Blaga University, Sibiu, Romania

The Banat is a region located on the boundary of Romania, Hungary and Serbia; its mountainous part (SW. Romania, adjacent part of Serbia) is geographically a continuation of the Carpathian Arch. Our field studies in July 2011, in the Romanian part of the Banat $\left(44.63-45.27^{\circ} \mathrm{N} ; 21.74-22.62^{\circ} \mathrm{E}\right)$, included 29 forest sites at various altitudes (104-928 $\mathrm{m}$ a.s.1.), of different substrata (limestone, schist), slope aspect, humidity and tree species composition. Samples were taken with standard methods (plots of $400 \mathrm{~m}^{2}, 2$ person-hours collecting by eye, 201 litter processed); in most cases they met the completeness criteria. Discounting slugs, 69 species were recorded (in the remaining regions of the Romanian Carpathians 83 species in all, in individual regions 35-56, mean 46). Faunistic similarity (Nei) between the Banat and other regions is $0.48-0.59$, mean 0.53 (similarities among the remaining regions $0.64-0.78$, mean 0.70 ). The species specific to the Banat and not found in the other regions are, for example Pomatias rivulare, Agardhia parreyssi, Gallandia annularis, Carpathica langi, Herilla ziegleri, Cochlodina marisi, Bulgarica rugicollis, B. pagana and Chilostoma trizona (the remaining regions have only $0-2$ specific species each). The similarities among the sites within the Banat is 0.51 (within the remaining regions $0.60-0.80$ ), and the between-site diversity measured with Whittaker's index $\mathrm{I}=3.37, \mathrm{I}_{\mathrm{MAX}}=2.23$ (the remaining regions: $\left.\mathrm{I}=1.48-2.40, \mathrm{I}_{\mathrm{MAX}}=1.20-1.61\right)$. The taxonomic structure of the fauna of the Banat and the remaining regions, expressed as the proportion of Pupilloidea, Zonitoidea, Clausiliidae and Helicoidea, as well as its biogeographical structure (proportion of widely distributed, Carpathian and Transylvanian components) are very similar while the ecological structure of the Banat malacocoenoses is characterised by a higher proportion of xerothermophilous species, compared to the remaining regions, whereas the structure of frequency is completely different. The Banat, though it differs from the remaining regions in the species composition of its malacocoenoses, between-site diversity, ecological and frequency structure of the fauna, taxonomically and biogeographically is a continuation of the Carpathians. The question if the Banat is a part of the Carpathians is the question of criteria of faunal divisions.

\section{MORPHOLOGICAL SIMILARITY AND GENETIC VARIATION OF TROCHULUS STRIOLATUS (C. PFEIFFER, 1828) AND T. MONTANUS (STUDER, 1820) (GASTROPODA: PULMONATA: HYGROMIIDAE)}

\author{
MAŁGORZATA PROĆKÓW ${ }^{1}$, TOMASZ STRZAŁA², \\ ELŻBIETA KUŹNIK-KOWALSKA ${ }^{3}$ \\ ${ }^{1}$ Muzeum Przyrodnicze, Uniwersytet Wrocławski, \\ Wrocław \\ ${ }^{2}$ Katedra Genetyki, Uniwersytet Przyrodniczy \\ we Wrocławiu, Wrocław \\ ${ }^{3}$ Zakład Systematyki i Ekologii Bezkręgowców, \\ Instytut Biologii, Uniwersytet Przyrodniczy \\ we Wrocławiu, Wrocław
}

Shell morphology has long been used for mollusc species identification. However, because of the wide variation and/or high degree of homoplasy of shell characters, it often fails to provide a reliable basis for systematic studies. This is true of many taxa, for example the genus Trochulus. Two nominal species: Trochulus striolatus (C. Pfeiffer, 1828) and T. montanus (Studer, 1820), are indistinguishable based on conchological characters and show only slight differences in their genitalia. They are found in north-western and western Europe: T. striolatus is common and widespread while T. montanus is limited to the Swiss and French Jura and likely to occur in the Italian Western Alps, though its exact range has not been specified. We used molecular, morphological and anatomical data to attempt a phylogeny reconstruction within a group including the two species and the sympatric T. caelatus (Studer, 1820) and T. sericeus (Draparnaud, 1801). Canonical discrimination analysis (CDA) of 14 shell characters confirmed the great morphological similarity between $T$. striolatus and $T$. montanus. No inter-population differences in shell morphology were found. However, the population of T. montanus from Château de Joux (France) differed from the remaining ones in the smaller shell size. Among T. striolatus, the population from Bath (UK) showed a distinctly greater relative height of body whorl (flatter shells). The analysis of 12 genital characters showed almost no differences between the species. The most significant contribution to the differences revealed by CDA was shown by the flagellum and upper vagina, but these characters cannot be reliably used to distinguish between the species. Phylogenetic analysis based on cytochrome oxidase (COI) sequences showed genetic distinctness of T. striolatus and T. montanus. The phylogenetic tree of 147 specimens of Trochulus (94 own sequences and 53 GenBank sequences) constructed with MrBayes programme, included two main clades joined by a node of $100 \%$ branch support. The first clade included all the sequences of T. striolatus from our own studies, 6 sequences of T. sericeus and 11 sequences of 
Trochulus sp. from GenBank. The second clade was mainly composed of sequences of $T$. montanus from our own studies, with those of $T$. clandestinus, $T$. caelatus, T. sericeus and an array of sequences of Trochulus sp. The division into two main species ( $T$. striolatus and T. montanus) was distinct and indisputable. However the distinctness of the remaining species is equivocal. Based on the tree, the closest relative of T. montanus is T. clandestinus and the two form a common branch in the tree. T. caelatus is located very close to the preceding two species, and is followed by $T$. sericeus. The systematic position of T. sericeus is difficult to ascertain, since its specimens in the tree are divided between the two main clades. The results show unequivocal genetic distinctness of $T$. striolatus and T. montanus. Further analysis of more numerous specimens and markers is required to ascertain the position of the remaining species, especially $T$. sericeus.

\section{IDENTIFICATION OF AQUAPORE-BUILDING AQUAPORINS IN ARION LUSITANICUS MABILLE, 1868 (GASTROPODA: PULMONATA: ARIONIDAE)}

\section{Alicja RABIASZ, EWA KoSICKA}

Zakład Biologii Komórki, Wydział Biologii, Uniwersytet im. Adama Mickiewicza w Poznaniu, Poznań

Aquaporins (AQP) are integral proteins commonly occurring in cell membranes. They form aquapores which are responsible for water transport across the membrane; sometimes they can also transport small polar molecules. For this reason aquaporins (water transport) and aquaglyceroporins (glycerol transport) are distinguished. The proteins play a crucial physiological role in bacteria, protists, fungi, plants and animals. There is no literature information on aquaporins in mollusc tissues. Few nucleotide sequences, which probably code for aquaporins and derive from a few mollusc species, are available in databases. None of the encoded proteins has been identified or its function studied. Using molecular techniques we identified a sequence, probably coding for aquaporin in a slug Arion lusitanicus (Arionidae); we called it AlAQP1. We analysed the sequence with bioinformatic methods to confirm that it really codes for aquaporin. The AlAQP1-encoded polypeptide shows all characters of aquaporin family, but its atypical amino-acid structure makes it impossible to assign it to any subfamily; also phylogenetic analysis failed to solve the problem. Mammal aquaporins are known to be tissue-specific, hence the next step will be identification of the expression level of $A l A Q P 1$ in various tissues and organs of $A$. lusitanicus. To sum up: we have identified in A. lusitanicus a sequence of AlAQP1, which probably codes for aquaporin, as confirmed by the bioinformatic analysis. The knowledge of amino-acid sequence of AlAQP1 alone does not permit precise ascertainment of the kind of transported molecules, or the speed of their transport. We are planning further experiments aimed at a functional characteristics of the aquapore built by AlAQP1.

\section{ASSESSMENT OF POPULATION DENSITY OF CEPAEA NEMORALIS AND C. HORTENSIS WITH TWO METHODS BASED ON MARKING-RELEASE-RECAPTURE}

\section{BRygida RADAWIEC, MAŁgORZATA OżGO}

Zakład Zoologii i Zakład Biologii Populacji, Akademia Pomorska, Słupsk

Population density of Cepaea nemoralis and C. hortensis was assessed in the village of Dretyn $\left(54^{\circ} 06^{\prime} \mathrm{N}\right.$, $16^{\circ} 58^{\prime} \mathrm{E}$, Pomerania) during the vegetation seasons 2009 and 2010. The material was collected in five sites of different habitats, using two methods of density assessment: Petersen-Lincoln's and Schnabel's. The size of sampling plots ranged from 13 to $100 \mathrm{~m}^{2}$. In the first variant the snails were collected from the plots twice, at a week's interval. The snails collected on the first occasion were marked and released. The proportion of marked individuals caught on the second occasion was the basis to calculate the population density. Using Schnabel's method we caught the snails five times at weekly intervals. On each occasion we marked the snails caught for the first time and the recaptured ones. The density was calculated as weighted mean of particular fractions of snails recorded during the whole study cycle. Nail varnish of four colours was used to mark the snails. The density ( \pm standard error) for $C$. nemoralis estimated with Petersen's method was $0.63 \pm 0.06$ to $11.61 \pm 2.53 \mathrm{ind} / \mathrm{m}^{2}$, depending on the site. Schnabel's method yielded slightly higher densities, within $0.84 \pm 0.02-11.6 \pm 0.23 \mathrm{indiv} / \mathrm{m}^{2}$. C. hortensis occurred only in three sites. Its density ranged from $0.42 \pm 0.06$ to $5.31 \pm 0.93 \mathrm{indiv} / \mathrm{m}^{2}$ (Petersen) and from $0.45 \pm 0.02$ to $6.62 \pm 0.22$ ind $/ \mathrm{m}^{2}$ (Schnabel). The methods differed much in the value of the relative error: for C. nemoralis it was $20.5-48.9 \%$ with Petersen's method and 3.9-7.1\% with Schnabel's method. The respective values for C. hortensis were 30.9-117.8\% and $6.5-11.6 \%$. 
MOLLUSCS IN SCHOOL TEXTBOOKS. ANALYSIS OF CONTENTS OF BIOLOGY TEXTBOOKS AT THE THIRD EDUCATIONAL LEVEL

\section{ELIZA RYBSKA, AGNiESZKA CiESZYŃSKA}

Wydziałowa Pracownia Dydaktyki Biologii i Przyrody, Wydział Biologii, Uniwersytet im. Adama

Mickiewicza w Poznaniu, Poznań

The first school textbooks were to help teachers educate the students. The Aristotelean "Historia animaliae" is regarded as the oldest biology textbook. Later, with decreasing printing costs, such books became a help for the student. It is accepted that textbooks order the information, make it more accessible, they often contain exercise material, play a motivational role etc. At present textbooks are accused of making the teacher lazy and the student - cognitively passive. Besides, it is thought that both teachers and students treat textbooks with complete faith, as exhaustive sources of knowledge. Textbooks are also the most often read sources in classes. From this point of view it is interesting to examine the information on molluscs which is found in the school textbooks approved by the Ministry of National Education. To what extent do such publications exhaust the subject in accordance with their function? How is the information selected and is it illustrated with examples? What do Polish students learn about molluscs from their textbooks? Does the way the contents is presented encourage the students to further learning? We analysed biology textbooks and exercise books for gymnasium schools. Our aim was to show possibilities and dangers posed by such books during education. To estimate whether the textbook fulfilled its functions we constructed indices for each function. All the analysed textbooks fulfilled the information function; other functions were only rarely fulfilled. Imprecision and erroneous information were common. Do textbooks have a chance to make students interested in malacology?

\section{LATE JURASSIC UNIONIDS FROM THE LOURINHĂ FORMATION, PORTUGAL}

\author{
ALEKSANDRA SKAWINA ${ }^{1}$, RUI CASTANHINHA ${ }^{2}$ \\ 1Zakład Fizjologii Zwierząt, Wydział Biologii, \\ Uniwersytet Warszawski, Warszawa \\ ${ }^{2}$ Instituto Gulbenkian de Cięncia, Oeiras e Săo \\ Juliăo da Barra, Portugal
}

The Lourinhă Formation in West Portugal is Late Jurassic in age (Kimmeridgian/Tithonian). The sediments are exposed in cliffs up to $50 \mathrm{~m}$ high, at the Atlantic Ocean coast. Episodes of marine transgressions and regressions were present, so the deposits of the Lourinhă Formation are of marine, brackish or fresh- water origin. These strata hold well known fossil tracks, bones and eggs of dinosaurs. Numerous marine bivalve fossils are present in the deposits, mostly preserved as external moulds (e.g. trigoniids, oysters, Nuculidae, Pectinidae, Isognomonidae). Several species of freshwater bivalves are also known. Unionoids are known in fossil record since the Late Triassic. However, their characteristic V-shaped umbonal sculpture appeared as late as in Middle Jurassic. This umbonal sculpture is sometimes well preserved in unionoid-like bivalves from the Lourinhă Formation. Such sculpture provides the basis for interpreting shell imprints as unionoids, and thus implies the freshwater origin of some layers of the Lourinhă Formation deposits.

\section{SHELL BIOMINERALIZATION RATE IN FRESHWATER BIVALVES OF THE GENUS UNIO IN NATURAL ENVIRONMENT: EXPERIMENTAL MEASUREMENTS OF SHORT-TERM DYNAMICS OF SHELL GROWTH}

\section{ALEKSANDRA SKAWINA ${ }^{1}$, JAROSŁAW STOLARSKI ${ }^{2}$ \\ ${ }^{1}$ Zakład Fizjologii Zwierząt, Wydział Biologii, Uniwersytet Warszawski, Warszawa ${ }^{2}$ Zakład Biogeologii, Instytut Paleobiologii, Polska Akademia Nauk, Warszawa}

The mechanism of mollusc shell bio-mineralization is still not well understood. It is thought that the shell grows periodically; in the wild the process may be regulated by the physiological biological clock or by cyclic external factors. Aragonite shells of unionid bivalves are composed of two calcareous layers: pearl layer, built of alternately arranged fine lamellae, prismatic layer of larger, vertical crystals, and the external, organic periostracum. Though generally shell increments are larger in young bivalves, in summer and in good trophic conditions (compared to older individuals, winter and starving bivalves), little is known about the rate of mineralization of consecutive shell crystals. Our studies were to determine the rate of shell bio-mineralization for members of the genus Unio in natural conditions, and to test the usefulness of calcein - a fluorescent dye - as an indicator of shell growth. Juvenile Unio tumidus were exposed in calcein-enriched environment for 30 minutes to 48 hours, and then placed in baskets in their natural habitat - littoral of Lake Mikołajskie. The bivalves were preserved at intervals of 3 hours to 14 days. Five days after the first marking the bivalves were subject to a 6 hour exposure to calcein, and then again placed in baskets in their natural habitat. Shell sections were examined in fluorescent microscope and in SEM. Calcein proved to be a good growth marker. All the individuals survived to the end of the experiment, and no calcein-induced shell disturbances were 
observed. The daily shell increment in Unio tumidus was on average $11 \mu \mathrm{m}$. The thickness of calcein-enriched layer in the prismatic layer was even, and decreased and/or dispersed to disappear in the pearl layer with distance from the shell edge. The calcein-enriched layer was uniformly inbuilt in both crystalline layers of the shell. The project was financed by grant from the Ministry of Science and Higher Education and Warsaw University, DSM no. 14-00-00/501/86-102348.

\section{SELECTED ASPECTS OF REPRODUCTION OF LYMNAEA STAGNALIS AND PLANORBARIUS CORNEUS (MOLLUSCA: GASTROPODA: PULMONATA) IN UKRAINE}

\section{T. L. SKOK}

Ukraine, Zhytomyr, Kybalchych str. 22, ap. 25, 10009

Morphometric examination of the reproductive system showed that Lymnaea stagnalis aged ca. one year reached hermaphroditic maturity in April-May, at the minimal shell height of 26.1-30.9 $\mathrm{mm}$. One-year Planorbarius corneus reached that stage in the first twenty days of April, at the minimal shell diameter of 14.1-19.2 mm. The minimum shell measurements of sexually mature specimens of both species increased from the woodland to the steppe regions of Ukraine. For this reason the "age class" does not correspond to the "size class" across the range of either species. The main reason for the inter-population differences in shell size at maturity is the growth rate and maturation rate variation among habitats. Consequently, measurements of the reproductive organs do not provide a reliable basis for species identification (unless the size-age population structure is considered). Compared to L. stagnalis, P. corneus shows a smaller fecundity, and the survival rate among older age classes is higher. $P$. corneus probably has lower mean mass and volume indices of reproductive effort, compared to L. stagnalis, and thus spends more energy on somatic metabolism support. Some differences in egg laying may be caused by ecological factors: deterioration in habitat conditions leads to decrease in intensity of gametogenesis and production of egg capsules, with increase in their mean volume and mass, and decrease in frequency of capsules with more than one embryo. The variation in syncapsules and their components makes them unreliable as diagnostic characters.

\section{GENETIC IDENTIFICATION OF SUBULINA OCTONA (BRUGUIÈRE 1798) IN THE PALM HOUSE IN POZNAŃ}

\author{
MARIANNA SOROKA ${ }^{1}$, ANNA SULIKOWSKA-DROZD ${ }^{2}$, \\ MARIA URBAŃSKA ${ }^{3}$ \\ ${ }^{1}$ Katedra Genetyki, Uniwersytet Szczeciński, Szczecin \\ ${ }^{2}$ Katedra Zoologii Bezkręgowców i Hydrobiologii, \\ Uniwersytet Łódzki, Łódź \\ ${ }^{3}$ Zakład Zoologii, Instytut Zoologii, Uniwersytet \\ Przyrodniczy w Poznaniu, Poznań
}

First reports on the occurrence of the tropical snail Opeas pumilum (L. Pfeiffer, 1840) in greenhouses in Poland (Poznań and Wrocław) date from the 1930s. For a long time the information was repeated by many authors but never verified. Now, differences in appearance were noticed which suggested that we might be dealing with a different species. To verify the taxonomic identity of the disputable specimens we carried out a comparative genetic analysis of snails from the Poznań Palm House and from a greenhouse in Leiden (the Netherlands) which had been identified as Subulina octona. Sequential analysis of a fragment of the mitochondrial gene $\operatorname{cox} 1$ revealed the presence of two distinct haplotypes one of which was characteristic of the Polish and the other of the Dutch specimens. Nucleotide variation between them was $1.4 \%$ and no mutation caused amino-acid change. The results show that the specimens from the Poznan Palm House represent S. octona. S. octona occurs in the Caribbean Islands and tropical regions of America, from where, with transports of horticultural products, it was introduced in other tropical and subtropical regions of the world. The species lives in leaf litter of tropical forests but is also found in greenhouses in North America and Europe (Austria, UK, the Czech Republic, Germany). In the Poznań Palm House it is found only in the tropical pavilions, with very high humidity (ca. $80 \%$ ) and constant temperature of $24^{\circ} \mathrm{C}$. S. octona does damage to plants, so molluscicides are used to control it. It is expected that regular use of molluscicides might completely eradicate the species in the Palm House. Probably in the 1930s, when Jarosław Urbański first reported O. pumilum in Poznań, his identification was correct. The conjecture is based on the conchological characters mentioned by Urbański and on the only published photograph. It is unknown how $O$. pumilum got replaced by $S$. octona, found at present in the Palm House. 
REPRODUCTIVE STRATEGIES OF BALEINE DOOR SNAILS (GASTROPODA: PULMONATA: CLAUSILIIDAE)

\section{ANNA SULIKOWSKA-DROZD ${ }^{1}$, TOMASZ K. MALTZ ${ }^{2}$, IZABELA JEDRZEJOWSKA ${ }^{3}$}

${ }^{1}$ Katedra Zoologii Bezkręgowców i Hydrobiologii, Uniwersytet Łódzki, Łódź

${ }^{2}$ Muzeum Przyrodnicze, Uniwersytet Wrocławski, Wrocław

${ }^{3}$ Zakład Biologii Rozwoju Zwierząt, Instytut Biologii Eksperymentalnej, Uniwersytet Wrocławski, Wrocław

Baleinae are among the five subfamilies of Clausiliidae which have representatives in Europe. The subfamily includes 7 genera with 51 species. Life cycles of 10 species (ca. $20 \%$ of all species) have been studied to date. Laboratory and field observations show, among other things, that they are iteroparous, long-lived, of determinate growth which terminates with completion of the closing apparatus and of delayed maturation of the reproductive system (shell growth completion precedes morphological and functional maturation of the reproductive system by 4-5 months). The species differ in their reproductive strategies: 4 species are oviparous, 3 show egg retention of various duration, another 3 are ovoviviparous. Three are capable of self fertilisation (egg retainers and ovoviviparous species). Anatomical and histological examination of the spermoviduct and free oviduct showed no histological differences between oviparous and ovoviviparous species (except $B$. perversa with its simplified structures inside the gonoduct). The system is semitriaulic, with three partly open channels: autospermiduct, allospermiduct and oviduct, within the spermoviduct; after separation of vas deferens, the oviduct with accompanying allospermiduct is referred to as uterus. Each channel is built of epithelium which is composed of basal cells with cytoplasmic processes and secretory cells. The structure of spermoviduct and free oviduct makes possible egg retention/ovoviviparity, but only some species use these structures for this purpose. Probable reasons for the variation in reproductive strategies should be sought in environmental conditions. Egg retention/ovoviviparity may be favoured by humid habitats, such as montane and submontane forests, habitats adjacent to lakes and rivers, as well as areas under the effect of oceanic climate. All the studied egg-retaining and ovoviviparous baleines occur in such habitats; their distribution ranges do not include regions with typically continental or Mediterranean climate. An example of special adaptation to ovoviviparity is the simplified closing apparatus of a species from oceanic climate - Balea perversa. The conical shape (like in juveniles of the remaining Baleinae), compensation growth after the onset of re- production, and small size indicate neoteny which may have evolved in a high-humidity environment.

\section{ISOTOPIC COMPOSITION OF THE SHELL OF VIVIPARUS DILUVIANUS (KUNTH) FROM INTERGLACIAL DEPOSITS IN ORTEL KRÓLEWSKI AND SZYMANOWO IN EASTERN POLAND}

\section{MARCIN SZYMANEK}

\section{Wydział Geologii, Uniwersytet Warszawski}

Shells of Viviparus diluvianus came from two localities of lacustrine deposits from Mazovian Interglacial in the environs of Biała Podlaska - Ortel Królewski and Szymanowo. The composition of stable isotopes of oxygen and carbon was determined in 13 samples: 6 from Ortel Królewski and 7 from Szymanowo. The shell height/width ratio in various parts of the interglacial was the selection criterion. In the first stage specimens corresponding to the mean height/width ratio of each sample representing a palynologically-distinguished part of the Masovian Interglacial were selected. Three to five complete adult shells of a similar age (the same number of whorls), but occurring at different times (different arrangement of growth lines), were ground and analysed. The values of $\delta^{18} \mathrm{O}$ and $\delta^{13} \mathrm{C}$ in Ortel Królewski were -7.73 to $-7.23 \%$ and -10.06 to $-9 \%$, respectively. The maximum value of $\delta^{18} \mathrm{O}$ in sample Or. $1.6-1.8 \mathrm{~m}$ corresponded to the yew phase of the Mazovian Interglacial and the greatest height/width ratio of $V$. diluvianus (1.41). Shells of the same height/width ratio from the optimum phase (Or. 0.5-0.7 m) had the smallest value of ${ }^{18} \mathrm{O}$, which was probably associated with deepening of the lake. Gradual increase in $\delta^{13} \mathrm{C}$ in the lower part of the profile indicates an improvement in climatic conditions. Maximum values corresponding to mid-interglacial cooling and drying of the climate (Or. 1.3-1.5 m) may result from shallowing of the lake. In Szymanowo the isotope curves for carbon and oxygen are within -8.61 $-7.77 \%$ and $-9.7--8.85 \%$, respectively. The samples represent the end of optimum and the post-optimum phase. The decrease in the values of $\delta^{18} \mathrm{O}$ and $\delta^{13} \mathrm{C}$ confirms deterioration of climatic conditions. The shifts of isotopic curve towards higher values correspond to the phase of cooling and shallowing of the lake, which is also manifest in palynological record and biometrical analysis of $V$. diluvianus. The project was financed by the National Science Centre, grant no. DEC2011/03/B/ST10/06329. 
MALACOFAUNA OF CAVE DEPOSITS FROM THE ROCK SHELTER IN SMOLEŃ IN THE WODĄCA VALLEY (CZESTOCHOWA UPLAND)

\author{
MARCIN SZYMANEK ${ }^{1}$, MACIEJ T. KRAJCARZ ${ }^{2}$, \\ MAGDALENA KRAJCARZ ${ }^{2}$, MAGDALENA SUdOŁ ${ }^{3}$ \\ ${ }^{1}$ Wydział Geologii, Uniwersytet Warszawski \\ 2Instytut Nauk Geologicznych, Polska Akademia \\ Nauk, Warszawa \\ ${ }^{3}$ Instytut Archeologii, Uniwersytet Mikołaja \\ Kopernika, Toruń
}

The study area is located in the central part of the Kraków-Częstochowa Upland, ca. 4 km SE of Pilica, 75 $\mathrm{km}$ SE of Częstochowa. The analysed malacofauna was obtained from cave deposits of Rock Shelter in Smoleń III, in the Wodaca Valley. Twelve layers were distinguished in the profile, from bottom to top: erosion loam (9), humic dust $(8)$, dust $(7,6)$, sandy dust $(5,5 a)$, dusty loam $(4,3)$, loam with charcoal ash (3a), dusty-humic loam $(2,1 \mathrm{a})$ and humic sandy dust (1). Mollusc shells were present in each layer, they were rather well preserved, though crumbled material occurred in places. Of the six examined plots, each of $1 \mathrm{~m}^{2}$, five are presented here. The assemblage included 63 terrestrial species of four ecological groups: shade-loving species (31 species); open-country species (7); mesophiles (14) and hygrophiles (1). Two sub-assemblages could be distinguished. The lower part of succession (layers 9, 8, 7) was very poor in species. The oldest, pre-Pleistocene, layer (9) yielded only two much fossilised and unidentifiable snail shells. In combined layers 8 and 7 only 14 taxa were identified, with cold-loving Semilimax kotulai and Vallonia tenuilabris, the latter species being characteristic of the Pleistocene; the deposition should be assigned to the pleniglacial. In the higher part of the profile the gradual increase in the number of species indicated an improvement in climatic conditions. Layers 6 and 5 still contained $V$. tenuilabris, forest species appeared in considerable numbers (e.g. Discus ruderatus), while the open-country Vallonia costata reached the highest frequencies. The assemblage probably represented the end of the Vistulian - late glacial. The fauna from layer 5 a should be associated with the same period or the beginning of Holocene. During the Holocene, forest-dwelling species became very numerous; the fauna included, among others, Discus ruderatus gradually replaced by $D$. rotundatus and D. perspectivus, Orcula doliolum, Ruthenica filograna, Cochlodina orthostoma, Isognomostoma isognomostoma and Vestia elata, the latter disappearing in layer 3. The preliminary results indicate that layers 4-2 should be assigned to the Middle, and layer 1 to the Upper Holocene. Further studies will make it possible to reconstruct the environmental conditions during their deposition. The field work was financed by the National Science Centre, grant no. 2011/01/N/HS3/01299.

\section{LONG-TERM CHANGES IN THE SEX RATIO OF POPULATIONS OF VIVIPARUS VIVIPARUS (LINNAEUS, 1758) (PECTINIBRANCHIA: VIVIPARIDAE) OF UKRAINE}

\section{Olena I. UVAEVA, TETYANA M. IVASHKIV, YULIA V. TARASOVA}

Ivan Franko Zhytomyr State University, Zhytomyr, Ukraine

Monitoring mollusc populations gains importance in view of increasing anthropopressure. One of suitable object for monitoring is Viviparus viviparus (Linnaeus, 1758). This species inhabits most of the rivers and lakes of Ukraine. The sex ratio is an important element of population structure, since it determines the reproductive success and thus recruitment of juveniles. Our study aimed at analysing long-term changes of sex ratio of different populations of $V$. viviparus in Ukraine, as well as their mortality and survival rates. In the summer and autumn of 2010-2012 we studied these parameters in populations from the Slutch River (city Sarni Rivne region). The primary sex ratio (i.e. sex ratio of snails aged less than one year which is not environment-affected) is often $1: 1$. The secondary sex ratio (older individuals) frequently deviates in favour of the proportion of females. Although among the individuals aged 1 or 2 years both sexes were equally numerous, sometimes males prevailed (July and September 2010, September 2012). There was a clear predominance of females among snails aged 4 years in the summer months, and in the autumn sometimes males of this age class were absent. The overall sex ratio of all age classes in 2010-2012 tended to be biased in favour of females, and was 0.4-0.8:1. This was associated with different mortality of males and females. The male mortality rate was $0.62-0.87$, the female rate being significantly lower: $0.48-0.67$. The sex ratio with predominance of females in water bodies under strong anthropopressure may be viewed as an adaptive strategy. 


\section{MOLLUSCS OF LAKE WIGRY (NE. POLAND)}

\section{BRYGIDA WAWRZYNIAK-WYDROWSKA}

Zakład Paleoocenologii, Uniwersytet Szczeciński, Szczecin

Molluscs in Lake Wigry (NE. Poland) were sampled in various seasons of 2009 and 2010 from 42 sites located in the whole lake, with various habitats (lake bottom - sediments, aquatic plants, hard submerged objects). Abiotic parameters of the water showed a great uniformity and lack of spatial differentiation; the prevailing effect on the water and sediment parameters was that of changes through time; biotic parameters of the water and sediments (chlorophyll a content as indicator of phytoplankton biomass, phycocyanin content) showed no distinct spatial variation, only locally the indices were higher, but temporal variation resulting from phytoplankton development was observed. In all, 48 taxa were recorded, 37 in the sediments (benthos), 42 among macrophytes and 3 on hard submerged objects (stones, timber). Forty five taxa were identified down to species level, three to the generic level; the fauna included 29 snail species and 16 bivalve species. Snails dominated on the macrophytes (28 taxa), while in the sediments the proportion of snails and bivalves was similar (20 and 17 taxa, respectively), The taxonomic structure and abundance varied among the habitats, the species diversity per habitat was rather small despite the large overall number of taxa. Species of the highest frequency in all three habitats were Dreissena polymorpha, Bithynia tentaculata, Radix balthica and Potamopyrgus antipodarum; in all the sites the dominant species were $P$. antipodarum and D. polymorpha; they also reached the highest absolute abundance. These two species were the only representatives of alien species in the lake. Most of the remaining species were rare or very rare and not abundant in the lake.

\section{MOLLUSCS OF ŻYWIEC (S. POLAND, BESKIDY MTS)}

\section{KAMILA ZAJĄC}

Uniwersytet Jagielloński, Kraków

The town of Żywiec is located in the Żywiec Basin which is a part of the Beskidy Zachodnie Mts. The relief is characteristic of highlands. The town has many patches which are floristically and faunistically rich. Field work was carried out from April to November 2012, in 22 sites within the town boundaries. The sites were selected to reflect the variety of habitats: Petasitetum, deciduous or deciduous-coniferous forests, riverine forests, xerothermic swards, anthropogenic habitats, copses, stone bar, rivers, fish ponds and a lake. Forty six species were recorded: 38 terrestrial and 8 freshwater ( 4 snails and 4 bivalves). The bivalves included the rare and endangered Anodonta cygnea. Land snails represented the following ecological groups: forest-dwellers $(68.42 \%)$, euryoecious species (15.79\%), hygrophiles $(5.26 \%)$, mesophiles $(5.26 \%)$, xerophiles $(2.63 \%)$ and open-country species $(2.63 \%)$. The high proportion of forest-dwellers was associated with the presence of extensive woodland areas within the town. Moreover, eight forest species were also found in other habitats. The richest habitats were the forests which were the least affected by human interference, making it possible for the fauna to survive in an unchanged form. 